\title{
A statistical meta-analysis of the wellbeing literature
}

\author{
Robert J. Eger · J. Haavard Maridal
}

\begin{abstract}
This study employs an empirical meta-analysis to examine the livability factors of wellbeing and assess each precursor's relative significance. The effect size results of individual studies of existing academic work are pooled by the use of a variety of statistical techniques to determine a meta-effect that yields statistically more significant conclusions and is a more powerful measure in that it has the ability to identify results closer to the true outcomes. The metaanalysis in this paper covers 164 studies and 560 observations published prior to September 2013. After articulating definitions of the central concepts and tenets of the scholarly research on wellbeing, the analysis continues with a literature review identifying recurring factors of wellbeing and the associated correlation. To address the variation in the type of analysis that underlies each study, all studies are converted to an effect size using Fischer's $z$ and then analyzed under the DerSimonian-Laird random-effects model. The results largely confirm the findings in the literature but also reveal some surprises and suggest avenues for future research. The metaanalysis finds empirical support for the dimensions of living standard, health, freedom, personal and community relationships, peace, and security as significant livability factors of wellbeing.
\end{abstract}

Keywords: philosophy, public policy, eudaimonia, life satisfaction

\section{Introduction}

The scholarly literature identifies a number of elements as contributors to wellbeing. The purpose of this study, which uses an empirical meta-analysis approach, is to assess the relative significance of the main factors of wellbeing discussed in the literature. The paper begins with a brief introduction to the history of the concept of wellbeing and then articulates definitions of the central concepts and tenets of the scholarly research in the field. A review of the academic literature in this area helps both to explain the dimensions associated with wellbeing and to identify the main components of wellbeing. The paper then describes the meta-analytic techniques employed and identifies methodological limitations before turning its attention to the meta-analysis itself, looking at each livability factor and its associated correlations. The paper ends with a discussion and implications.

\subsection{Brief history of the concept of wellbeing}

In the past, happiness denoted a concept comparable to the term 'objective wellbeing' used today. In ancient Greece, and in both Christian and Eastern wisdom and religious literature, happiness signified a life worth living and the truly happy person pursued virtue over the course of a lifespan. Happiness was a holistic concept in the vein of the Greek poet Hesiod's and the historian Herodotus' eudaimonia (a virtuous and flourishing life), the Roman philosopher Cicero's summum bonum (the highest good), and the medieval philosopher and theologian Thomas Aquinas' sublime beatitudo (the Godly life). Historically, happiness had also been associated with luck, fortune, or divine favor. In this way, it was seen by some as being beyond 
a person's control to a certain extent (McMahon, 2006). Traditional perceptions of happiness began to change on two fronts during the Age of Enlightenment in the $18^{\text {th }}$ century. First, the emphasis on virtue as a necessary path to flourishing and wellbeing was diminished in favor of a focus on pleasure and the absence of pain, something most strongly evident in Jeremy Bentham's (1789) philosophy of Utilitarianism. Second, the pursuit of this new form of happiness was elevated as the principal purpose of human life. As a consequence of these ideas, happiness came to be defined more narrowly - not as wellbeing in a broad and inclusive sense but rather, as in Bentham, as a good feeling.

This relatively new conception of happiness has given rise to a growing body of popular and academic literature seeking to discover how happiness, life satisfaction, and wellbeing are achieved. The academic literature focuses primarily on positive psychology, studying how individuals can feel better, and on economics, trying to understand how people and governments can make welfare-enhancing choices. Despite these focus areas, happiness research is becoming increasingly important in most of the social sciences. Academia and popular literature are not the only clusters of society concerned with wellbeing, however; attempts are increasingly being made by agencies in the governmental sphere to use research on wellbeing to inform policy, with the aim of increasing overall societal wellbeing. An example of this is the United Kingdom's recent efforts in measuring national and personal wellbeing through the Office for National Statistics (Office for National Statistics, 2014).

\subsection{Theoretical background}

A universal definition of wellbeing has somewhat eluded scholars. In the academic and popular literature, the terms quality of life, happiness, life satisfaction, and prosperity are often used interchangeably with wellbeing. However, as statistical analysis of population surveys and dictionary definitions suggest, these terms differ in their nuances. Happiness is increasingly used to describe momentary pleasant emotions, while life satisfaction is used to refer to long-term cognitive evaluation of life as a whole, a sort of deeper happiness. Prosperity, on the other hand, tends to be used in discussions of tangible economic conditions. Sociologist Ruut Veenhoven, considered by some to be the father of happiness studies, has argued that wellbeing should be used to denote quality of life overall (Frisch, 2013).

This study defines wellbeing as a composite of the two underlying concepts of happiness and life satisfaction. Although this definition has roots in ancient literature, as exemplified by Thomas Aquinas' delineation of sublime beatitudo (McMahon, 2006), Bradburn and Noll (1969) may have been the first modern scholarly work to emphasize the idea that wellbeing is composed of both evaluative and joy- or pleasure-based effects. Campbell, Converse, and Rodgers (1976) drew a contrast between life satisfaction and happiness, describing the former as "a judgmental or cognitive experience" and the latter as "an experience or feeling of affect" (p. 8). In this vein, Lane (2000) argued that happiness represented a marginal emotional change. Further support for this distinction can be found in Diener, Kahneman, Tov, and Arora (2010); Helliwell, BarringtonLeigh, Harris, and Huang (2009); Kahneman (1999); and Lucas, Diener, and Suh (1996). A quick analysis of self-report surveys supports the distinction between happiness and life satisfaction: the correlation between the two concepts in the World Values Survey (1981-2005) is only .47, for example, signifying that the two are different, albeit related, concepts. Along these lines, as the terms are used in this study life satisfaction describes a cognitive judgment and happiness refers to an emotional state. 


\subsection{Evaluative wellbeing and affective wellbeing}

Scholarly research increasingly uses the terms evaluative wellbeing (EWB) and hedonic wellbeing (HWB). In Kahneman and Deaton (2010) and Graham (2010), EWB is defined as a global, contemplative, long-term assessment, a state of wellbeing that is reflective of one's sense of quality of life-not at a given point in time but rather over the course of one's life. HWB refers to a person's present, and potentially more transient, state of wellbeing as measured by the positive or negative affects experienced immediately or daily.

In this study, however, preference is given to the term affective wellbeing (AWB) in place of HWB to describe a person's present or experienced state of wellbeing. The concern is that hedonic is not an accurate descriptor for experienced wellbeing because one's momentary, experienced feelings and emotions are not necessarily concerned solely with pleasure. Rather, it is possible for them to stem instead from a deep inner joy as explained by the Greek concept of eudaimonia, Cicero's expression of the summum bonum, or Thomas Aquinas' sublime beatitudo. According to this understanding, one's present wellbeing derives not only from bodily pleasures but also from personality traits and temperaments, including prudence (according to Aristotle's Ethics, book 9 and 10) (Rackham, 1934), personal choice (Seligman, 2002a, 2002b), and states of mood that may be hereditary or genetically determined (Lykken, 1999).

As depicted in Figure 1 below, EWB and AWB can be imagined as a continuum, with EWB on the pure cognitive, evaluative end and AWB on the pure immediacy, affective end. Life satisfaction is more closely aligned with the former and immediate or experienced happiness with the latter.

\section{Figure 1: Wellbeing - Life Satisfaction and Happiness on the EWB-AWB}

$\begin{array}{ccc}\text { Pure Cognition Life Satisfaction } & \text { Affective } \\ \text { Evaluative } & \text { Wappiness } \\ \text { Wellbeing (EWB) } & \text { Wellbeing (AWB) }\end{array}$

EWB and AWB both emanate from two primary categories of sources: livability and lifeability. Livability denotes environmental, societal factors, in which a person finds himself or herself, and lifeability describes the internal, personal dynamics that enable this person to benefit from his or her environment.

Scholarly literature distinguishes between subjective and objective wellbeing (Arneson, 1999; Parfit, 1984; Scanlon, 1993; Sumner, 2003). Subjective wellbeing (SWB) refers to a person's particular experience of his or her own life and can be measured through self-report methods such as population surveys. Objective wellbeing (OWB) consists of a list of quantifiable social or economic indicators that a scholar theorizes are determinants of quality of life (Sen, 1999).

In SWB surveys, questions can range from the very long-term and evaluative (EWB) to the very immediate and emotional (AWB). Responses to questions like those in Cantril's selfanchoring ladder (1965) fall on the extreme EWB side of the EWB-AWB continuum and are more strongly correlated with life satisfaction. ${ }^{1} \mathrm{AWB}$ questionnaires measure respondents' present affects. These questions may use a positive and negative affect schedule (Watson, Clark, \&

\footnotetext{
${ }^{1}$ A typical question measuring life satisfaction might ask: “All things considered, how satisfied are you with your life as a whole these days? Use a scale from 1-10 where 1 means you are 'completely dissatisfied' and 10 means you are 'completely satisfied.'”
} 
Tellegen, 1988), which falls on the extreme AWB side of the continuum and responses correlate more strongly with happiness. ${ }^{2}$ Table 1 below presents a classification of the concepts introduced thus far.

Table 1: Classification of Wellbeing Concepts

\begin{tabular}{|c|c|c|}
\hline \multicolumn{3}{|c|}{ Subjective Variables Of Wellbeing (SWB) } \\
\hline Underlying Concept & Life Satisfaction (EWB) & Happiness (AWB) \\
\hline Level Of Perception & $\begin{array}{l}\text { Cognitive, evaluative, reflective, } \\
\text { long term }\end{array}$ & $\begin{array}{l}\text { Emotional, mood or affect- } \\
\text { based, sensory, short term }\end{array}$ \\
\hline Potential Measurements & $\begin{array}{l}\text { Cantril's self-anchoring ladder, } \\
\text { questionnaire (scale from 1-10) }\end{array}$ & $\begin{array}{l}\text { Day reconstruction method, } \\
\text { positive and negative affect } \\
\text { schedule (PANAS) }\end{array}$ \\
\hline \multicolumn{3}{|c|}{ Objective Variables Of Wellbeing (OWB) } \\
\hline Concept & $\begin{array}{l}\text { Livability dimensions } \\
\text { (environmental, external factors) }\end{array}$ & $\begin{array}{l}\text { Lifeability dimensions } \\
\text { (individual, internal factors) }\end{array}$ \\
\hline Elements & $\begin{array}{l}\text { Friends, family, peace, freedom, } \\
\text { health, income, wealth, } \\
\text { opportunity, etc. }\end{array}$ & $\begin{array}{l}\text { Degree of purpose and meaning } \\
\text { to life, attitudes, life choices, } \\
\text { heredity }^{3}\end{array}$ \\
\hline Potential Measurements & $\begin{array}{l}\text { Numerical indicators of income, } \\
\text { health, family, crime, etc. }\end{array}$ & $\begin{array}{l}\text { Brain-scanning, revealed } \\
\text { preferences, questionnaires }\end{array}$ \\
\hline
\end{tabular}

\section{Literature review}

Using the theoretical classification, this study's focus is on factors of wellbeing that stem from livability. To explore the extant literature on the factors of livability, six groupings are identified through a review of the academic literature on wellbeing. These groupings are living standard; health and environment; freedom; community and relationships; peace and security; and opportunity.

\subsection{Living standard}

The factor 'Living standard' is concerned with the material resources available to people in a society and is often measured through economic and financial indicators. The living standard effect is at the center of Jeremy Bentham's (1789) economic utility theory and a substantive component of Maslow's (1943) hierarchy of needs. Economic utility theory suggests that as individuals gain income and wealth, they gain purchasing power, which expands the bundle of goods they can afford, leading to increased consumption and, ultimately, improved wellbeing. Considerable disagreements exist in the literature regarding the degree to which income and wealth contribute to wellbeing. Currently, the science seems to have settled on an understanding that the cognitive evaluation of one's life (i.e., one's life satisfaction) is considerably and positively impacted by increases in living standard, while happiness is impacted only up to medium income levels (approximately $\$ 75,000$ according to Kahneman and Deaton (2010)). Increased financial

\footnotetext{
${ }^{2}$ It is important to emphasize that the difference between happiness and life-satisfaction is also determined by the way questions are framed in the surveys. A question measuring happiness that would fall closer to the AWB side of the continuum is: "Presently, would you describe yourself as: (1) Very happy, (2) Rather happy, (3) Not very happy, or (4) Not at all happy?"

${ }^{3}$ Determined by genetic factors and therefore able to be passed on from parents to their offspring or descendants.
} 
resources can, however, impact people's wellbeing through means other than direct consumption. Dunn, Aknin, and Norton (2008) found that spending money on other people created more happiness than did spending money on oneself, a finding supported by Zak (2011). Income is also highly correlated with health and, to a certain degree, with opportunity.

\subsection{Health and environment}

The factor 'health and environment', as related to wellbeing, deals with the prevailing physical, mental, and environmental conditions for individuals in a society. Although Graham (2008) and others have pointed out that people adjust surprisingly well to both negative and positive changes in their health, research has found wellbeing is greater for people who enjoy good physical and mental health. Research supporting this hypothesis includes Bee and Bjorklund (2000); Dolan and White (2007); Heylighen (1999); Katsaiti (2012) and Kushner and Foster (2000). Research, however, has found health and wellbeing is a non-recursive system. Blakeslee and Grossarth-Maticek (1996) showed that wellbeing is highly predictive of future good health. Some of the objective indicators of health identified in the literature include life expectancy, undernourishment, suicide rates, positive experiences, mental and physical suffering, and air, water, and sanitation quality.

\subsection{Freedom}

Freedom concerns the extent to which people are in control of their own lives. Sen (1999) was among the first to propose that freedom is a "bundled commodity" consisting of political, economic, civil, and religious categories. The magnitude of freedom can be measured by the degree to which there is respect for political, civil, religious, and economic freedoms in a society as well as by people's perceptions of these freedoms. Triandis and Gelfand (1998) say that although absolute freedom in all areas may be counterproductive, dynamic social systems and cultures have a tendency to combine a sense of social responsibility and solidarity with a high degree of freedom for people to follow their personal moral compasses to make key choices for themselves. Gundelach and Kreiner (2004) and Verme (2007) find freedom to be the component possessing the overall strongest correlation to wellbeing. Other research supporting the correlation between increased wellbeing and freedom in general includes Heylighen (1999), Brooks (2008a, 2008b), and (Veenhoven, 2008, 2012). More specifically, Diener, Diener, and Diener (1995) found that political freedom and civil liberties enhance wellbeing, while Gropper, Lawson, and Thorne (2011) found that economic freedom augments wellbeing.

\subsection{Community and relationships}

The factor 'community and relationships' relates to the quality of the community, family life, and friendships in a society. According to social causation theory (Joung, 1997; Mastekaasa, 1992), community and family relations increase wellbeing by providing emotional and financial support to the individual. This support serves as a buffer against the travails of life, thereby preserving or increasing wellbeing. The empirical literature has found that deep human interactions are directly beneficial to the individual's emotional state and feeling of wellbeing. There is also an indirect effect through higher social capital and lower transaction costs that leads to economic growth and an increased standard of living. Empirical support for the importance of close-knit community interaction for wellbeing can be found in Stolle (1998), Putnam (2000), Guiso, Sapienza, and Zingales (2006), and Zak (2011). Religious engagement as a precursor for higher wellbeing has been identified by Lim and Putnam (2010), Winkelmann and Winkelmann 
(1998), Ellison and Levin (1998), Diener and Suh (1997), Veenhoven (1996), Wilson (1967), Helliwell (2008), and Inglehart (2010). Drummond (2000), Plagnol and Easterlin (2008), Helliwell and Putnam (2004), Diener, Gohm, Suh, and Oishi (2000), Kahneman and Krueger (2006), and Veenhoven (2012) provide support for marriage and family life as important aspects of people's wellbeing.

\subsection{Peace and security}

The factor 'peace and security' relates to sources of instability in a society such as the level of violence and crime; and also to trust, transparency, corruption, and bureaucratic quality, or efficiency. In addition to community and freedom, peace is one of those factors humans need in order to thrive. Competent governance, in the sense of the minimization of violence, crime, corruption, and cronyism, fosters a peaceful society. Research that has found some of the foregoing impact wellbeing includes Oishi (2012), Oishi and Roth (2009), Inglehart (1990), Frey and Stutzer (2000), Inglehart and Klingemann (2000), and Diener, Inglehart, and Tay (2013).

\subsection{Opportunity}

Opportunity is concerned with people's access to things like community basics (i.e. workable infrastructure) education, employment, and entrepreneurship that enables them to live satisfying and happy lives. The link between opportunity and wellbeing on a societal level is a highly mobile economic and social environment. A society with high levels of opportunity is an environment that does not discriminate. It is one that allows equal prospects for all when it comes to pursuing the good life. As such, the factor 'opportunity' is closely related to the factors 'freedom' and 'living standard'. The opportunity to work, satisfaction with one's job, and the prospect of pursuing entrepreneurial undertakings have been found to be strong explanatory factors of wellbeing according to Frankl (1963), Brooks (2008a, 2008b), and Murray (1988), among others. Opportunity is especially important to the underprivileged, and poverty sometimes results from a lack of opportunity. Research supporting the link between poverty and wellbeing includes Biswas-Diener and Patterson (2011), Marshall et al. (2001) and Oishi, Kesebir, and Diener (2011). According to Meulemann (2001), education might also be an important driver of opportunity.

\section{Methodology}

The theoretical background and scholarly literature support the operationalization of these six categories. The review of the scholarly literature introduced the reader to the most recurring findings based on these groupings. It provides an opportunity to explore and test, through a meta-analysis, the linkage of these livability aspects with wellbeing.

By offering the opportunity to combine evidence from retrospectively accumulated or prospectively generated data, meta-analysis is an important research tool that increases statistical power by combining results from studies that have similar or related research hypotheses. The effect size results of individual studies are pooled by use of a variety of statistical techniques to determine a meta-effect, which is a more powerful measure of the outcome. In addition to increased statistical power, other advantages include greater generalizability and increased ability to do multifactor analyses. Using meta-analysis shifts the focus from an individual study's statistical significance towards the true effect size.

The meta-analysis in this paper was performed by first asking whether the factors identified in the literature impact wellbeing. A systematic literature search was performed based on the 
specified factors. Several search techniques were used to retrieve studies for inclusion. Articles written in a language other than English were considered if they had been translated into English. Identification was achieved through electronic library databases including JSTOR, ProQuest, Web of knowledge, and Dissertation Abstracts International, the Web-based search engine Google Scholar, and the Web-based World Database of Happiness (Veenhoven, 2013). Computerized searches involved multiple combinations of terms reflecting wellbeing (life satisfaction, satisfaction with life, happiness, quality of life, emotional wellbeing, subjective wellbeing, and wellbeing).

The studies identified as relevant were then reviewed and, when inclusion/exclusion criteria were deemed similar, graded for quality. Judgments about the quality of studies was based on design, follow-up, and outcome assessments. The inclusion/exclusion criteria for the selection process were as follows:

1. The study must involve participants of working age who reside within the geographic location investigated;

2. The study must include a nationally representative sample;

3. A measure of wellbeing must be clearly defined;

4. An objective measure of at least one of the proposed factors within the literature on livability must be present; and

5. The study must be publically available with results presented in a correlation or a convertible metric that is conducive to computational conversion into an effect size.

Meta-analysis is particularly influenced by the external validity of each of the examined studies. Here, external validity refers to the generalization of research findings either from a sample to a larger population or to settings and populations other than those studied. To address external validity, assessment is based on (1) the extent to which empirical measures accurately reflect the stated theoretical constructs, (2) whether the research setting conforms to the scope of the theory under test, (3) a subjective assessment regarding confidence that the findings presented may be repeated under identical conditions, and (4) the confirmatory status of the theory under test. In these ways, external validity is principally seen as a theoretical issue and can be addressed only by an examination of the interplay between theory and methods.

All potentially relevant studies published or posted through September of 2013 were considered for inclusion. Every attempt was made to be inclusive; however, the criteria for inclusion and exclusion does not guarantee that every relevant study is identified using these criteria. Selected articles were then abstracted.

\subsection{Fixed effects (FE) vs. random effects (RE)}

Given that meta-analysis is the focus of this study, the distinction between fixed effects (FE) and random effects (RE) models is a critically important topic because there is a strange anomaly in the behavioral and social sciences today. The anomaly is the fact that although the FE models are almost never appropriate, the majority of published meta-analyses in social science in general and some related areas have been based on FE models. This is not the case in either the industrial and organizational psychology literature and certain other literatures such as management studies, organizational behavior, and business strategy (Hunter \& Schmidt, 2000).

Inference under a meta-analysis framework indicates that if there is real variation in population parameters across studies, the FE model not only cannot detect this variation, but also produces confidence intervals (CIs) that are erroneously narrow. That is, the FE model greatly underestimates the amount of uncertainty in the estimated mean value. Of course, the FE 
model produces accurate results when there is zero variance across studies in the population values. The problem is that there are few if any study sets that meet this condition (Hunter \& Schmidt, 2000). On the other hand, RE models produce accurate results in both cases: when there is and is not variation in study population values.

Evidence of the anomaly and of the use of FE models is explored in (Schmidt, Oh, \& Hayes, 2009). Using two different RE methods to reanalyze the data from five FE-based meta-analysis publications in Psychological Bulletin that included a total of 54 separate meta-analyses, they found that the average level of underestimation of the width of the CIs by the FE models was $55 \%$. That is, the FE CIs are, on average, less than half as wide as the actual CIs. This amounts to a very serious overestimation of the degree of certainty of the mean effect sizes. Hence, the use of FE models instead of RE models does not lead to merely technical anomalies. It leads to major errors.

Hedges and Vevea (1998) and Overton (1998) point to a possible reason for the use of FE methods. They suggest that the choice of a FE or RE model depends on the type of inference that is the goal of the meta-analysis. If the goal is to draw conclusions that are limited to the set of studies at hand, and there is no desire to generalize beyond the particular set of studies included in the analysis, the FE model can be used when population parameters vary and when they do not. Hedges and Vevea (1998) refer to this as conditional inference. The usual goal of research, however, is generalizable knowledge (Toulmin, 1961), which requires generalization beyond the current set of studies to other similar studies that have been or might be conducted. Hedges and Vevea (1998) refer to this as unconditional inference.

The objective of this meta-analysis is to make unconditional inferences about a wide population of studies; that is, to draw conclusions that can be generalized beyond the specific set of studies included in the presented meta-analysis. The methodological purpose, therefore, is to reach conclusions that are not limited to the specific set of studies in the meta-analysis, because the set of studies at hand is viewed as a sample of a larger number of studies that might exist or could be conducted (Hedges \& Vevea, 1998; Hunter \& Schmidt, 2000; Overton, 1998; Murray et al., 1994). In this case, generalization of conclusions is an important aspect of the study and the RE model is offered in the analysis, i.e., the inference of cumulative knowledge (Field, 2005; Hedges \& Vevea, 1998; Murray et al., 1994).

To address variation in the type of analysis that underlies each study, all studies are converted to an effect size using Fischer's $z$ and then analyzed under the DerSimonian-Laird random-effects model. This model assumes heterogeneity between the studies; that is, it assumes that the true effect can be different for each study. The model assumes that the true effects of individual studies are distributed with a variance $\tau^{2}$ around an overall true effect, but the model makes no assumptions about the form of the distribution of either the within-study or the between-studies effects.

\subsection{Addressing publication bias}

Once a study included in this meta-analysis has been subjectively assessed for external validity, based on both statistical methods and theory, the results and implications of that study are assessed for publication bias. Publication bias is the term for what occurs whenever the research that appears in the published literature is systematically unrepresentative of the population of completed studies. Simply put, when the research that is readily available differs in its results from the results of all the research that has been done in an area, readers and reviewers of that research are in danger of drawing the wrong conclusion about what that body of research shows. 
Although publication bias has likely been around for as long as research has been conducted and reported, it has come to prominence in recent years largely with the introduction and widespread adoption of the use of systematic review and meta-analytic methods to summarize research. In part, this is because, as methods of reviewing have become more scientific and quantitative, the process of reviewing (and synthesizing) research has been increasingly seen as paralleling the process of primary research. Parallels to the threats to the validity of primary research have been uncovered at every step of the systematic review process (Cooper, 1998; Shadish, Cook, \& Campbell, 2002). Publication bias is a non-trivial issue. Evidence that publication bias has had an impact on meta-analyses has been firmly established by several lines of research (Rothstein, Sutton, \& Borenstein, 2005). Thus, a problem that was viewed hazily through the looking glass of traditional reviews came into sharp focus under the lens of metaanalysis.

To address the threat of publication bias, this study uses the Egger, Smith, Schneider, and Minder (1997) regression method, which tests for a linear association between the intervention effect and its standard error. Alternative methods, such as that of Begg and Mazumdar (1994), which proposed testing the interdependence of variance and effect size using Kendall's method, may also be applicable in testing for publication bias. Although Begg and Mazumdar (1994) make fewer assumptions than do Egger et al. (1997), the method of Begg and Mazumdar (1994) is insensitive to many types of bias to which the test of Egger et al. (1997) is sensitive. As suggested by Sterne, Gavaghan, and Egger (2000), in cases where the number of studies in the meta-analysis is small, the Begg and Mazumdar (1994) method has very low power to detect bias. Given the number of studies available for several of the livability factors in this meta-analysis, the Egger et al. (1997) test for publication bias was used.

\subsection{Descriptive results}

Table 2 below reports the descriptive count of the studies meeting the criteria of inclusion in the meta-analysis. The total count of observation is 560 with 164 unique studies identified. This indicates that on average each study contributed about 3.4 observations. In the meta-analysis, each country or geographical area that is uniquely identified is considered an observation. This is not to say that each unique study provides information on a single geographical entity; in fact, many of the uniquely identified studies may offer generalizable information. Unique studies may also offer multiple components or factors that are independently assessed.

Table 2: Study count

\begin{tabular}{cc}
\hline Number of Observations & 560 \\
Number of Unique Studies & 164 \\
\hline
\end{tabular}

Table 3 below reports the tests for validity based on publication bias using Egger et al. (1997). Using p-values, the results indicate the presence of potential publication bias for one of the components, GDP per capita, at the conventional $p=0.05$ level. This analysis is presented to assist in formulating overall inferences for each of the livability factors presented above. 


\section{Living standard}

Current living standards

GDP per capita (PPP adjusted, real, and logged)

Are you satisfied or dissatisfied with your standard of living, all the

things you can buy or do?

$$
\mathrm{p}=0.03
$$

$\mathrm{p}=0.10$

Improvement in living standards

5-year growth rate of GDP per capita

Right now, do you feel your economic situation is getting better or getting worse?

$\mathrm{p}=0.89$

$\mathrm{p}=0.28$

\section{Freedom}

Political rights

$\mathrm{p}=0.21$

Civil liberties

$\mathrm{p}=0.35$

Economic freedom

$\mathrm{p}=0.19$

Overall perception of freedom: Are you satisfied or dissatisfied with your freedom to choose what to do with your life?

$\mathrm{p}=0.99$

\section{Health and environment}

Physical health

Life expectancy at birth

$\mathrm{p}=0.33$

Infant mortality rate

$p=0.07$

Mental and emotional health

Suicide rate

$p=0.21$

Environmental health

Air quality

$p=0.67$

\section{Community and relationships}

Community life

Family life

Religious engagement

$p=0.75$

Are you married?

$p=0.10$

Peace, stability and security

Political and ethnic violence

Violence and ethnic warfare

$p=0.09$

Human rights violations

$\mathrm{p}=0.33$

Trust in national institutions

$\mathrm{p}=0.89$

Corruption in business and government

Control of corruption

$\mathrm{p}=0.42$

World indexes: Corruption index

$\mathrm{p}=0.58$

Bureaucratic quality

$\mathrm{p}=0.23$

\section{Opportunity}

Unemployment

$\mathrm{p}=0.80$

The concern in Table 3 above is the component GDP per capita, which is one of the underlying components of the factor of livability, 'Living standard'. GDP per capita has 50 studies associated with it, as offered in Figure 2 below. The visual assessment of these 50 studies identifies an asymmetric outcome. The asymmetry indicates strong evidence that studies with a one-sided 
significance test are suppressed and those with a two-sided significance test are not. This adds further credence to the possibility that the asymmetry observed in the contour plot offered in Figure 2 below is caused by publication bias.

Figure 2: Contour funnel plot for GDP per capita

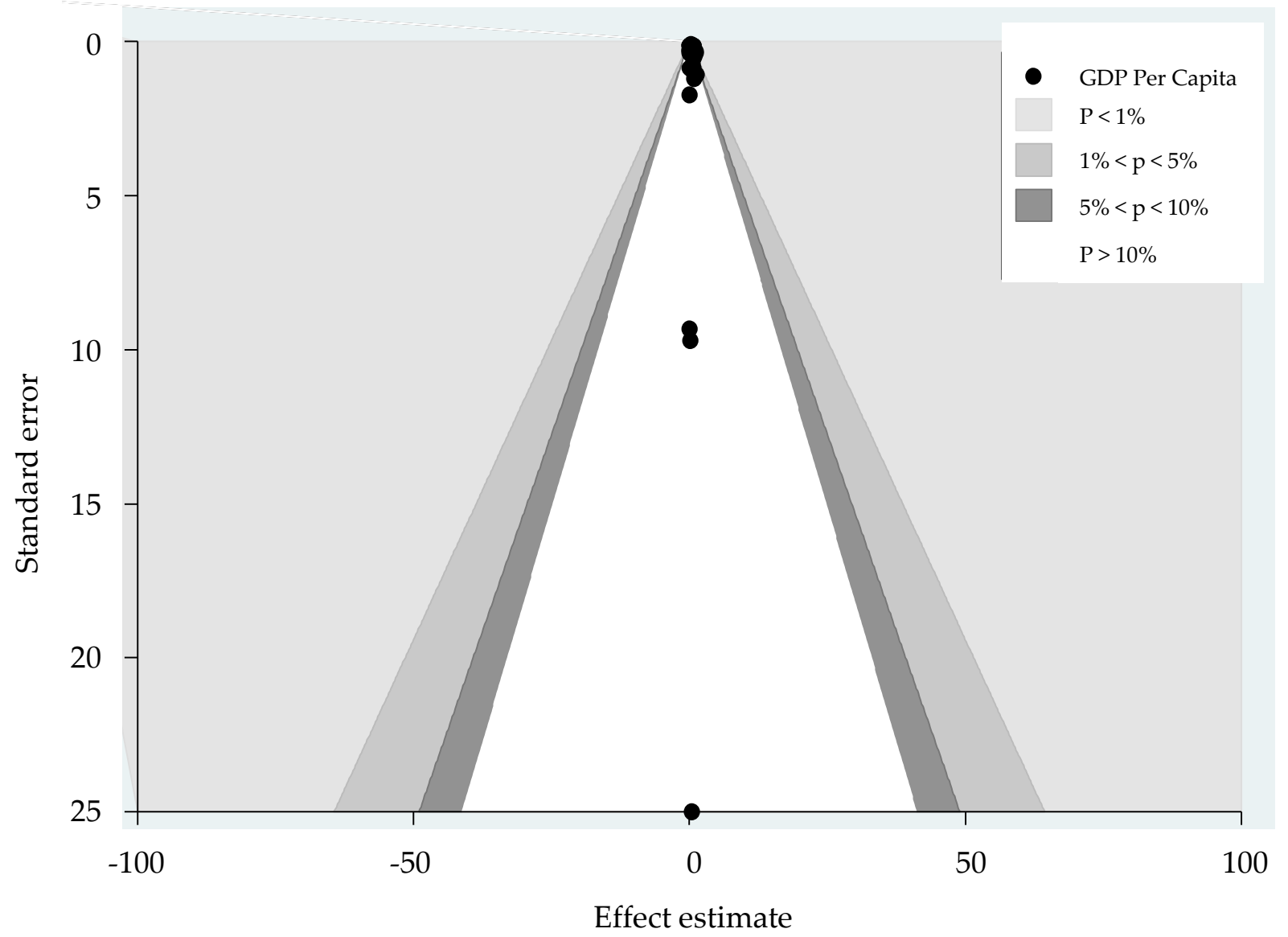

\section{Meta-analysis results}

Based on this study's theoretical discussion, there are three effect sizes offered in these metaanalyses. The first effect size, WB, is a measure of the correlation with wellbeing ignoring differences associated with affective wellbeing represented by happiness ( $\mathrm{AWB}$ ) and evaluative wellbeing represented by life satisfaction $(\mathrm{EWB})$. The second measure of correlation uses affective wellbeing $(\mathrm{AWB})$ alone. As discussed, ${ }_{\mathrm{A}} \mathrm{WB}$ is closely related to an immediate state of wellbeing that is reflected in one's current emotional state. The data show that 132 of the 560 observations can be considered ${ }_{\mathrm{A}} \mathrm{WB}$ studies. The third effect size offered in the meta-analysis is articulated as evaluative wellbeing $(\mathrm{EWB})$. $\mathrm{EWB}$ is advanced as a cognitive, reflective state where individuals evaluate their wellbeing over longer periods of time. In the data, 428 observations are categorized as $\mathrm{EWB}$. In addition to the three effect sizes, the $95 \%$ confidence intervals (CI) and the observation counts are reported. Appendix A provides a listing of all the studies associated with the metaanalyses.

\subsection{Living standard}

The analysis for the first factor of livability, 'Living standard', is presented in Table 4. From a wellbeing perspective, several components underlie 'Living standard' in the literature. Two of these are Current living standard and Improvement in living standard. Within Current living 
standard, an objective measure and two subjective measures are offered in the literature. The objective measure, GDP per capita, has 50 observations in the prior literature. Measures of GDP per capita include adjusted and real; for example, Samanni and Holmberg (2010) and Fahey and Smyth (2004), respectively. The effect size for all 50 observations is a correlation of 0.53 with wellbeing and is statistically significant with a CI lower limit of 0.47 and an upper limit of 0.58 . When considering ${ }_{\mathrm{A}} \mathrm{WB}$ and $\mathrm{EWB}$, the correlation is stronger with $\mathrm{EWB}$ and the $\mathrm{CI}$ is narrower, providing some evidence that the effect of income and wealth is stronger when the individual considers his or her life satisfaction (wellbeing over time) than it is for happiness (one's emotional state), a result supporting Kahneman and Deaton (2010). For Current living standard, the prior literature has measured only the subjective question, "Are you satisfied or dissatisfied with your standard of living, all the things you can buy or do?" as a component. Examples in the prior literature include Andrews and Withey (1976) and Headey, Veenhoven, and Wearing (1991). Sixty-four observations are found for this subjective component with a mean correlation of 0.34 , a weaker correlation than found for the objective measure, GDP per capita. The results indicate that $\mathrm{EWB}$ has a stronger correlation than is found with ${ }_{\mathrm{A}} \mathrm{WB}$, with $\mathrm{EWB}$ having a narrower $\mathrm{CI}$.

Table 4: Livability Factor-Living standard

\begin{tabular}{|c|c|c|c|c|c|c|c|c|c|}
\hline & \multicolumn{3}{|c|}{$\begin{array}{l}\text { Average Effect Size } \\
\text { (correlation) }\end{array}$} & \multicolumn{3}{|c|}{ 95\% Confidence Interval } & \multicolumn{3}{|c|}{$\begin{array}{c}\text { Number of } \\
\text { Observations }\end{array}$} \\
\hline & WB & ${ }_{A} W B$ & EWB & WB & AWB & EWB & WB & ${ }_{\mathrm{A}} \mathbf{W B}$ & EWB \\
\hline \multicolumn{10}{|c|}{ Current living standards } \\
\hline \multicolumn{10}{|l|}{ GDP per } \\
\hline $\begin{array}{l}\text { capita (PPP } \\
\text { adjusted, real, } \\
\text { and logged) }\end{array}$ & 0.53 & 0.39 & 0.58 & $0.47,0.58$ & $0.28,0.48$ & $0.51,0.64$ & 50 & 14 & 36 \\
\hline \multicolumn{10}{|l|}{ Are you } \\
\hline $\begin{array}{l}\text { dissatisfied } \\
\text { with your } \\
\text { standard of }\end{array}$ & 0.34 & 0.24 & 0.37 & $0.31,0.36$ & $0.17,0.30$ & $0.33,0.40$ & 64 & 16 & 48 \\
\hline $\begin{array}{l}\text { living, all the } \\
\text { things you can } \\
\text { buy or do? }\end{array}$ & & & & & & & & & \\
\hline \multicolumn{10}{|c|}{ Improvement in living standards } \\
\hline \multicolumn{10}{|l|}{ 5-year growth } \\
\hline $\begin{array}{c}\text { per capita. } \\
\text { Right }\end{array}$ & & & & & & & & & \\
\hline now, do you & & & & & & & & & \\
\hline $\begin{array}{l}\text { feel your } \\
\text { economic } \\
\text { situation is }\end{array}$ & 0.09 & 0.17 & 0.00 & $0.01,0.17$ & $0.09,0.24$ & $-0.09,0.10$ & 8 & 4 & 4 \\
\hline getting better & & & & & & & & & \\
\hline or getting & & & & & & & & & \\
\hline worse? & & & & & & & & & \\
\hline
\end{tabular}

Within Improvement in living standard, an objective measure and two subjective measures are offered. The objective measure, 5-year growth rate of GDP per capita, which is the chosen proxy for Improvement in living standard, contains 41 observations in the prior literature. Statistical 
significance is found for both $\mathrm{AWB}$ and $\mathrm{EWB}$, although the correlations are in opposite directions. For ${ }_{\mathrm{A}} \mathrm{WB}$ the 5-year growth rate is negatively associated with immediate happiness, which is quite possible given that the 5-year growth rate is measuring a reflective aspect of wellbeing. The finding, however, may support Graham's (2010) thesis of short-run "unhappy growth." The same observation holds true for the positive correlation between $\mathrm{EWB}$ and the 5-year growth rate, which signals that the reflective measure is positively correlated with the reflective measure of wellbeing. The effect size for wellbeing is a statistically insignificant correlation of 0.03 . This is most likely due to the reflective nature of the 5-year growth rate in which ${ }_{\mathrm{AWB}}$ and $\mathrm{EWB}$ are pulling the wellbeing outcome in different directions. For Improvement in living standard, the prior literature has measured only the subjective question, "Right now, do you feel your economic situation is getting better or getting worse?" as a component. Eight observations are found for this subjective component with a mean correlation of 0.09 , a stronger correlation than found with the 5-year growth rate of GDP per capita. The results indicate that $\mathrm{AWB}$ has a stronger correlation than is found with $\mathrm{EWB}$, with EWB found to be statistically insignificant. The result is to be expected as the variable addresses people's personal changes in income.

\subsection{Freedom}

The analysis for the livability factor, 'Freedom', is presented in Table 5. Four components are identified and used in the prior literature. Within 'Freedom', Political rights is offered in the prior literature. The effect size for all 28 observations for Political rights is a correlation of 0.16 with wellbeing. This correlation is statistically significant with a CI lower limit of 0.08 and an upper limit of 0.24 . When considering ${ }_{\mathrm{A}} \mathrm{WB}$ and $\mathrm{EWB}$, the correlation is weaker with $\mathrm{EWB}$, providing some evidence that Political rights is stronger when individual wellbeing is considered as happiness.

Table 5: Livability Factor-Freedom

\begin{tabular}{|c|c|c|c|c|c|c|c|c|c|}
\hline & \multicolumn{3}{|c|}{$\begin{array}{l}\text { Average Effect Size } \\
\text { (correlation) }\end{array}$} & \multicolumn{3}{|c|}{ 95\% Confidence Interval } & \multicolumn{3}{|c|}{$\begin{array}{c}\text { Number of } \\
\text { Observations }\end{array}$} \\
\hline & WB & AWB & EWB & WB & AWB & EWB & WB & ${ }_{A}$ AWB & EWB \\
\hline Political rights & 0.16 & 0.22 & 0.14 & $0.08,0.24$ & $0.08,0.34$ & $0.05,0.24$ & 28 & 6 & 22 \\
\hline Civil liberties & 0.23 & 0.28 & 0.22 & $0.14,0.32$ & $0.11,0.43$ & $0.11,0.31$ & 23 & 6 & 17 \\
\hline $\begin{array}{l}\text { Economic } \\
\text { freedom }\end{array}$ & 0.35 & 0.35 & 0.35 & $0.26,0.42$ & $0.16,0.52$ & $0.24,0.43$ & 28 & 4 & 24 \\
\hline $\begin{array}{l}\text { Overall } \\
\text { perception of } \\
\text { freedom: Are you } \\
\text { satisfied or } \\
\text { dissatisfied with } \\
\text { your freedom to } \\
\text { choose what to do } \\
\text { with your life? }\end{array}$ & 0.24 & 0.19 & 0.28 & $0.18,0.28$ & $0.14,0.24$ & $0.20,0.35$ & 21 & 10 & 11 \\
\hline
\end{tabular}

The next component of 'Freedom' is Civil liberties. Twenty-three observations are found for Civil liberties with a mean correlation of 0.23 . The results indicate that $\mathrm{EWB}$ has a weaker correlation than is found with ${ }_{\mathrm{A}} \mathrm{WB}$ based on magnitude, although $\mathrm{EWB}$ has a narrower $\mathrm{CI}$. The component Economic freedom has an average correlation with wellbeing of 0.35 . The correlation is consistent across both ${ }_{\mathrm{A}} \mathrm{WB}$ and $\mathrm{EWB}$, with $\mathrm{EWB}$ and wellbeing reflecting similar CIs. The final component 
of 'Freedom' that is observed in the prior literature is Overall perception of freedom. The average correlation for Overall perception of freedom is 0.24 with $\mathrm{EWB}$ showing the strongest correlation. In the literature, limitations exist on the correlation between wellbeing and religious freedom due to a lack of longitudinal data on religious freedom.

\subsection{Health and environment}

Three components are identified as underlying the third livability factor, 'Health and environment'. Beginning with Physical health, two sub-components are present in the extant literature. Life expectancy at birth, in Table 6, shows a statistically significant average correlation of 0.11 with wellbeing. The strongest correlation for Life expectancy at birth is found with ${ }_{\mathrm{A}} \mathrm{WB}$, with an average correlation of 0.27 . The reported correlation for Infant mortality rate is -0.14 , indicating that as infant mortality increases wellbeing decreases. All studies found in the extant literature using the criteria offer only $\mathrm{EWB}$ when estimating the effect of wellbeing and infant mortality. Studies measuring the relationship between overall Mental and emotional health in a society and its overall wellbeing are sparse in the existing literature. The empirical findings focus on Suicide rate. This component has the fewest studies meeting the inclusion criteria of all the components found in the literature reviewed for this meta-analysis. The negative correlation of 0.14 is bolstered by a single study associated with EWB that shows a correlation of -0.25 . If that study is ignored, as shown in the ${ }_{\mathrm{A}} \mathrm{WB}$ column, the resulting correlation of Suicide rate with wellbeing is statistically insignificant. The final component underlying the livability factor 'Health and environment' is Environmental health. Of the three sub-components of health identified in academic works, only one sub-component, Air quality, is measured in the extant literature. Although the correlation for this sub-component is -0.03 , the outcome is a statistically insignificant correlation.

Table 6: Livability Factor-Health and environment

\begin{tabular}{|c|c|c|c|c|c|c|c|c|c|}
\hline & \multicolumn{3}{|c|}{$\begin{array}{l}\text { Average Effect Size } \\
\text { (correlation) }\end{array}$} & \multicolumn{3}{|c|}{ 95\% Confidence Interval } & \multicolumn{3}{|c|}{$\begin{array}{c}\text { Number of } \\
\text { Observations }\end{array}$} \\
\hline & WB & AWB & EWB & WB & ${ }_{\mathrm{A}} \mathrm{WB}$ & EWB & WB & AWB & EWB \\
\hline \multicolumn{10}{|l|}{ Physical health } \\
\hline $\begin{array}{l}\text { Life } \\
\text { expectancy } \\
\text { at birth }\end{array}$ & 0.11 & 0.27 & 0.02 & $0.07,0.16$ & $.012, .041$ & $0.01,0.04$ & 15 & 5 & 10 \\
\hline $\begin{array}{l}\text { Infant } \\
\text { mortality rate }\end{array}$ & -0.14 & & -0.14 & $-0.24,-0.02$ & & $-0.24,-0.02$ & 6 & 0 & 6 \\
\hline \multicolumn{10}{|c|}{ Mental and emotional health } \\
\hline Suicide rate & -0.14 & -0.11 & -0.25 & $-0.04,-0.23$ & $0.00,-0.22$ & & 5 & 4 & 1 \\
\hline \multicolumn{10}{|c|}{ Environmental health } \\
\hline Air quality & -0.03 & & -0.03 & $-0.15,0.09$ & & $-0.15,0.09$ & 6 & 0 & 6 \\
\hline
\end{tabular}

\subsection{Community and relationships}

The analysis for the fourth livability factor, 'Community and relationships', is presented in Table 7. In academic works two major components are identified that relate to 'Community and relationships', Community life and Family life. Table 7 presents both components, noting that Community life contains Religious engagement only. Unfortunately, longitudinal data does not exist for secular community engagement in the literature used in the meta-analysis. Religious engagement is significantly positively correlated with wellbeing for $\mathrm{EWB}$. The effect size of 
Religious engagement is insignificant for the ${ }_{\mathrm{A}} \mathrm{WB}$ studies. Given the relatively small number of observations from ${ }_{\mathrm{A}} \mathrm{WB}$ studies, the statistically significant correlation for wellbeing results is dominated by the ${ }_{\mathrm{E}} \mathrm{WB}$ studies overall. The component Family life has one sub-component, Are you Married?, which meets the criteria for this study. Are you Married? is positively correlated with all the wellbeing measures, with a correlation of about 0.06 (WB) and a CI lower limit of 0.03 and an upper limit of 0.08 .

Table 7: Livability Factor-Community and relationships

\begin{tabular}{|c|c|c|c|c|c|c|c|c|c|}
\hline & \multicolumn{3}{|c|}{$\begin{array}{c}\text { Average Effect Size } \\
\text { (correlation) }\end{array}$} & \multicolumn{3}{|c|}{ 95\% Confidence Interval } & \multicolumn{3}{|c|}{$\begin{array}{c}\text { Number of } \\
\text { Observations }\end{array}$} \\
\hline & WB & AWB & EWB & WB & AWB & EWB & WB & AWB & EWB \\
\hline $\begin{array}{l}\text { Community Life } \\
\text { Religious } \\
\text { Engagement } \\
\text { Family Life }\end{array}$ & 0.07 & -0.02 & 0.07 & $0.03,0.11$ & $-0.08,0.04$ & $0.03,0.12$ & 87 & 6 & 81 \\
\hline $\begin{array}{l}\text { Are you } \\
\text { Married? }\end{array}$ & 0.06 & 0.07 & 0.05 & $0.03,0.08$ & $0.05,0.10$ & $0.02,0.08$ & 73 & 21 & 52 \\
\hline
\end{tabular}

\subsection{Peace, stability, and security}

The analysis for the livability factor 'Peace, stability, and security' is presented in Table 8. The major components observed in the literature that underlie 'Peace, stability, and security' are identified as Political and ethnic violence, Human rights violations, Law and order, Trust in national institutions, Corruption in business and government, and Bureaucratic quality. The results for Political and ethnic violence indicate that wellbeing is negatively correlated with Political and ethnic violence for $\mathrm{AWB}$, a correlation of -0.28 , showing that in the immediacy associated with $\mathrm{AWB}$ increases in Political and ethnic violence reduce wellbeing. The correlation with wellbeing is not statistically significant with either WB or $\mathrm{EWB}$. The Human rights violations component shows a positive correlation of -0.20 with wellbeing. When considering ${ }_{\mathrm{A}} \mathrm{WB}$ and $\mathrm{EWB}$, the correlation is stronger with $\mathrm{AWB}$, providing some evidence that Human rights violations is stronger when the individual considers his or her immediate wellbeing. The next component is Trust in national institutions. No statistically significant correlation is found for Trust in national institutions and wellbeing. Corruption in Business and Government is composed of two sub-components, both of which have been used in prior studies that meet the inclusion criteria. The sub-component Control of corruption is positively correlated with all three measures of wellbeing. A correlation of 0.40 is associated with wellbeing, which is similar to both the ${ }_{\mathrm{A}} \mathrm{WB}$ and $\mathrm{EWB}$ correlations. ${ }_{\mathrm{A}} \mathrm{WB}$ has the strongest correlation with Control of corruption at an average of 0.47 . The Corruption index shows a negative correlation with wellbeing as measured in the WB and $\mathrm{AWB}$ measurements. The Corruption index is statistically correlated with the $\mathrm{EWB}$ measure of wellbeing. The results for Bureaucratic quality, or efficiency, indicate a positive correlation across all measures of wellbeing. 
Table 8: Livability Factor-Peace, stability, and security

\begin{tabular}{|c|c|c|c|c|c|c|c|c|c|}
\hline & \multicolumn{3}{|c|}{ Correlation } & \multicolumn{3}{|c|}{ 95\% Confidence Interval } & \multicolumn{3}{|c|}{$\begin{array}{c}\text { Number of } \\
\text { Observations }\end{array}$} \\
\hline & WB & ${ }_{\mathrm{A}} \mathrm{WB}$ & EWB & WB & AWB & EWB & WB & AWB & EWB \\
\hline $\begin{array}{l}\text { Political and } \\
\text { Ethnic } \\
\text { Violence }\end{array}$ & 0.14 & -0.28 & 0.27 & $-0.16,0.41$ & $-0.43,-0.13$ & $-0.02,0.52$ & 8 & 2 & 6 \\
\hline $\begin{array}{l}\text { Human rights } \\
\text { violations }\end{array}$ & -0.20 & -0.33 & -0.13 & $-0.11,-0.29$ & $-0.19,-0.45$ & $-0.03,-0.24$ & 27 & 10 & 17 \\
\hline $\begin{array}{l}\text { Trust in } \\
\text { national } \\
\text { institutions }\end{array}$ & 0.10 & 0.02 & 0.12 & $-0.01,0.20$ & $-0.07,0.12$ & $-0.01,0.24$ & 9 & 2 & 7 \\
\hline Corruption in & 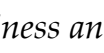 & 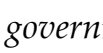 & & & & & & & \\
\hline $\begin{array}{l}\text { Control of } \\
\text { corruption }\end{array}$ & 0.40 & 0.47 & 0.39 & $0.30,0.50$ & $0.01,0.76$ & $0.29,0.48$ & 11 & 2 & 9 \\
\hline $\begin{array}{l}\text { Corruption } \\
\text { index }\end{array}$ & -0.27 & -0.54 & -0.14 & $-0.47,-0.05$ & $-0.71,-0.30$ & $-0.37,0.10$ & 10 & 3 & 7 \\
\hline $\begin{array}{l}\text { Bureaucratic } \\
\text { quality }\end{array}$ & 0.37 & 0.40 & 0.37 & $0.29,0.45$ & $0.14,0.62$ & $0.28,0.44$ & 19 & 4 & 15 \\
\hline
\end{tabular}

\subsection{Opportunity}

The analysis for the final livability factor, 'Opportunity', is presented in Table 9. In the literature, there are at least four components that underlie 'Opportunity'. These are entrepreneurship, community basics, education, and employment. Although the literature has four major components for 'Opportunity', the inclusion criteria limit the analysis to Employment. Table 9 presents the results for Employment. The objective measure, Unemployment, has 21 observations assessed from the prior literature. The effect size for all 21 observations is a correlation of 0.04 with wellbeing and is statistically insignificant, with a CI lower limit of -0.04 and an upper limit of 0.11 . When considering ${ }_{\mathrm{AWB}}$ and $\mathrm{EWB}$, the correlation is statistically insignificant with $\mathrm{EWB}$, but it is statistically significant for ${ }_{\mathrm{A}} \mathrm{WB}$ with a correlation of 0.19 ; thereby leading to an assessment that individuals consider their immediate wellbeing when considering employment. This finding may seem surprising, but the outcome is intuitive if we consider that unemployment is a temporary individual effect that can change in a very short period of time.

Table 9: Livability Factor-Opportunity

\begin{tabular}{lccccccccc}
\hline & \multicolumn{3}{c}{$\begin{array}{c}\text { Average Effect Size } \\
\text { (correlation) }\end{array}$} & \multicolumn{2}{c}{ 95\% Confidence Interval } & \multicolumn{3}{c}{$\begin{array}{c}\text { Number of } \\
\text { Observations }\end{array}$} \\
\hline & WB & AWB & EWB & WB & AWB & EWB & WB & AWB & EWB \\
\hline $\begin{array}{l}\text { Employment } \\
\text { Unemployment }\end{array}$ & 0.04 & 0.19 & 0.01 & $-0.04,0.11$ & $0.01,0.35$ & $-0.06,0.09$ & 21 & 3 & 18 \\
\hline
\end{tabular}

\section{Conclusion}

This study has investigated, through a meta-analysis, the livability factors and associated components identified in the literature as contributors to wellbeing. Using the theoretical background associated with wellbeing, two constructs observed in the literature underpin wellbeing: happiness and life satisfaction. Using the meta-analysis, the findings support the underlying constructs associated with wellbeing-happiness, which is identified as ${ }_{\mathrm{A}} \mathrm{WB}$ in the 
analysis; and $\mathrm{EWB}$, the identifier for life satisfaction. The meta-analysis of the prior empirical literature shows that the two constructs differ in regard to the magnitude and statistical significance of their correlations as they relate to wellbeing, supporting the hypothesized continuum derived through the synthesis of the theoretical literature.

The main findings of the analyses are that all six livability factors are present within the prior literature, although the frequency with which the components of these factors are used varies. The livability factor identified as 'Living standard' has strong representation in the empirical literature, with dozens of studies using this factor. The results for 'Living standard' show that the underlying components are all positively related to wellbeing, with variability in magnitude found with both ${ }_{\mathrm{A}} \mathrm{WB}$ and $\mathrm{EWB}$. The results for 'Living standard' are indicative of those found with the livability factors 'Freedom' and 'Community and relationships,' although 'Freedom' has correlation coefficients approximately 50\% smaller than those found with 'Living standard'. Correlations of 'Community and relationships' are approximately $50 \%$ smaller than those found with 'Freedom'. The implication for these three livability factors is that all three are important when investigating the implications of wellbeing, but that the magnitudes of the impacts are different.

For the other three livability factors, 'Health and environment,' 'Peace, stability, and security,' and 'Opportunity,' the results show that these three factors are correlated with wellbeing although their representation in the literature is substantially lower than that the other three livability factors. One reason may be the difficulty in measuring these livability factors, in addition to the possibility that these factors have become of interest rather recently within the literature. The importance of these livability factors is quite apparent, with many of the correlations with wellbeing at around a modest magnitude of 0.15 . This leads to the conclusion that ignoring these three livability factors might produce erroneous assumptions about wellbeing - in particular, about each underlying construct of wellbeing, happiness, and life satisfaction.

This meta-analysis is used to answer questions not posed by the individual studies. The selection of studies based on the criteria laid down for this meta-analysis is focused on providing estimates that may help improve or settle controversies arising from apparently conflicting studies regarding the factors of wellbeing. Statistical analysis of findings allows the degree of conflict to be formally assessed and reasons for different results to be explored and quantified as social science assessments of wellbeing advance in the literature. The meta-analysis has also discovered the need for further studies of wellbeing that include multiple dimensions of wellbeing simultaneously in order to capture indirect relationships, spurious effects, and other matters of interest.

The empirical value of this meta-analysis is to increase statistical power and improve precision, since significance level and the estimation of effect-size can be improved when they are based on more information. Some of the components have a small number of prior studies associated with them, which directly impacts the value of the meta-analysis for those variables. The results for some of the components and sub-components in small studies should encourage researchers to continue to explore the influence of these components and sub-components on wellbeing.

This study explores the effects of all the research found to date regarding ${ }_{\mathrm{AWB}} \mathrm{EWB}$, and wellbeing. The promise of enhancing our understanding of the role of wellbeing in the world encourages future research, as wellbeing and its underlying constructs continue to provide important information to policy-makers throughout the world. 


\title{
Acknowledgments
}

This research was sponsored by a grant from the Charles Koch Institute.

\author{
Authors \\ Robert J. Eger \\ Naval Postgraduate School \\ rjeger@nps.edu \\ J. Haavard Maridal \\ Baylor University

\section{Publishing Timeline}

Received 11 August 2014

Accepted 27 March 2015

Published 21 June 2015

\section{References}

Andrews, F. M., \& Withey, S. B. (1976). Social indicators of well-being: Americans' perceptions of life quality. New York: Plenum Press. http://dx.doi.org/10.1007/978-1-4684-2253-5

Arneson, R. J. (1999). Human flourishing versus desire satisfaction. Social Philosophy and Policy, 16(01), 113-142. http://dx.doi.org/10.1017/S0265052500002272

Bee, H. L., \& Bjorklund, B. R. (2000). The journey of adulthood (4th ed.). Upper Saddle River, NJ: Prentice Hall.

Begg, C. B., \& Mazumdar, M. (1994). Operating characteristics of a rank correlation test for publication bias. Biometrics, 50(4), 1088-1101. http://dx.doi.org/10.2307/2533446

Bentham, J. (1789). An introduction to the principles of morals and legislation. Oxford: Clarendon Press.

Biswas-Diener, R., \& Patterson, L. (2011). Positive psychology and poverty. In R. Biswas-Diener (Ed.), Positive psychology as social change (125-140). Dordrecht, The Netherlands: Springer.

Blakeslee, T. R., \& Grossarth-Maticek, R. (1996). Feelings of pleasure and well-being as predictors of health status 21 years later. http://www.attitudefactor.com/PWItecharticle.htm

Bradburn, N. M. \& Noll, C. E. (1969). The structure of psychological well-being. Chicago: Aldine Pub. Co.

Brooks, A. C. (2008a). Free people are happy people-Especially when strong personal morality guides their choices. City Journal 18(2), 31.

Brooks, A. C. (2008b). Gross national happiness: Why happiness matters for America-And how we can get more of it. New York: Basic Books.

Campbell, A., Converse, P. E., \& Rodgers, W. L. (1976). The quality of American life: Perceptions, evaluations, and satisfactions. New York: Russell Sage Foundation.

Cantril, H. M. (1965). Pattern of human concerns. New Brunswick, NJ: Rutgers University Press.

Cooper, H. M. (1998). Synthesizing research: A guide for literature reviews (Applied Social Research Methods, Vol. 2). Thousand Oaks, CA: Sage Publications.

Diener, E., Diener, M., \& Diener, C. (1995). Factors predicting the subjective well-being of nations. Journal of Personality and Social Psychology, 69(5), 851-864. http://dx.doi.org/10.1037/0022-3514.69.5.851

Diener, E., Gohm, C. L., Suh, E., \& Oishi, S. (2000). Similarity of the relations between marital status and subjective well-being across cultures. Journal of Cross-cultural Psychology, 31(4), 419-436. http://dx.doi.org/10.1177/0022022100031004001

Diener, E., Inglehart, R., \& Tay, L. (2013). Theory and validity of life satisfaction measures. Social Indicators Research, 112(3), 497-527. http://dx.doi.org/10.1007/s11205-012-0076-y

Diener, E., Kahneman, D., Tov, W., \& Arora, R. (2010). Income's association with judgments of life versus feelings. In E. Diener, D. Kahneman, \& J. F. Helliwell (Eds.), International differences in well-being (315). Oxford, United Kingdom: Oxford University Press. 
Diener, E., \& Suh, E. (1997). Measuring quality of life: Economic, social, and subjective indicators. Social Indicators Research, 40(1-2), 189-216. http://dx.doi.org/10.1023/A:1006859511756

Dolan, P., \& White, M. P. (2007). How can measures of subjective well-being be used to inform public policy? Perspectives on Psychological Science, 2(1), 71-85. http://dx.doi.org/10.1111/j.17456916.2007.00030.x

Drummond, N. (2000). Quality of life with asthma: The existential and the aesthetic. Sociology of Health $\mathcal{E}$ Illness, 22(2), 235-253. http://dx.doi.org/10.1111/1467-9566.00201

Dunn, E. W., Aknin, L. B., \& Norton, M. I. (2008). Spending money on others promotes happiness. Science, 319(5870), 1687-1688. http://dx.doi.org/10.1126/science.1150952

Egger, M., Smith, G. D., Schneider, M., \& Minder, C. (1997). Bias in meta-analysis detected by a simple, graphical test. $B M J, 315(7109), 6$. http://dx.doi.org/10.1136/bmj.315.7109.629

Ellison, C. G., \& Levin, J. S. (1998). The religion-health connection: Evidence, theory, and future directions. Health Education \& Behavior, 25(6), 700-720. http://dx.doi.org/10.1177/109019819802500603

Fahey, T., \& Smyth, E. (2004). The link between subjective well-being and objective conditions in European societies. In W. A. Arts, \& L. Halman (Eds.), European values at the turn of the millennium (Vol. 7), 57-80. Leiden, The Netherlands: Koninklijke Brill NV.

Field, A. (2005). Discovering statistics using SPSS (2nd ed.). London: Sage.

Frankl, V. E. (1963). Man's search for meaning (I. Lasch, Trans.). (Original work published 1946). New York: Pocketbooks.

Frey, B. S., \& Stutzer, A. (2000). Happiness, economy and institutions. The Economic Journal, 110(466), 918-938. http://dx.doi.org/10.1111/1468-0297.00570

Frisch, M. B. (2013). Ruut Veenhoven: Pioneer on empirical fresearch on happiness. http://www2.eur.nl/fsw/research/veenhoven/interviews/AppliedResearchQOL 2013.pdf

Graham, C. (2008). Happiness and health: Lessons - and questions - for public policy. Health Affairs, 27(1), 72-87. http://dx.doi.org/10.1377/hlthaff.27.1.72

Graham, C. (2010). The challenges of incorporating empowerment into the HDI: Some lessons from happiness economics and quality of life research. Human Development Reports Research Paper, Documento de investigación, 2010/13, 1-54. New York: United Nations Development Programme.

Gropper, D. M., Lawson, R. A., \& Thorne, J. T., Jr. (2011). Economic freedom and happiness. The Cato Journal, 31, 237-255.

Guiso, L., Sapienza, P., \& Zingales, L. (2006). Does culture affect economic outcomes? The Journal of Economic Perspectives, 20(2), 1-48. http://dx.doi.org/10.1257/jep.20.2.23

Gundelach, P., \& Kreiner, S. (2004). Happiness and life satisfaction in advanced European countries. Cross-Cultural Research: Official journal of the Society for Cross-Cultural Research, Sponsored by the Human Relations Area Files, Inc, 38(4), 359. http://dx.doi.org/10.1177/1069397104267483

Headey, B., Veenhoven, R., \& Wearing, A. (1991). Top-down versus bottom-up theories of subjective well-being. Social Indicators Research, 24(1), 81-100. http://dx.doi.org/10.1007/BF00292652

Hedges, L. V., \& Vevea, J. L. (1998). Fixed- and random-effects models in meta-analysis. Psychological Methods, 3(4), 486-504. http://dx.doi.org/10.1037/1082-989X.3.4.486

Helliwell, J. F. (2008). Life satisfaction and quality of development (Working paper 14507). Cambridge, MA: National Bureau of Economic Research. http://dx.doi.org/10.3386/w14507

Helliwell, J. F., Barrington-Leigh, C. P., Harris, A., \& Huang, H. (2009). International evidence on the social context of well-being (Working paper 14720). Cambridge, MA: National Bureau of Economic Research. http://dx.doi.org/10.3386/w14720

Helliwell, J. F., \& Putnam, R. D. (2004). The social context of well-being. Philosophical Transactions of the Royal Society of London Series B Biological Sciences, 359(1449), 1435-1446.

http://dx.doi.org/10.1098/rstb.2004.1522

Heylighen, F. (1999). Happiness. In F. Heylighen, C. Joslyn \& V. Turchin (Eds.) Principia Cybernetica Web. Brussels, Belgium.

Hunter, J. E., \& Schmidt, F. L. (2000). Fixed effects vs. random effects meta-analysis models: Implications for cumulative research knowledge. International Journal of Selection and Assessment, 8(4), 275-292. http://dx.doi.org/10.1111/1468-2389.00156 
Inglehart, R. (1990). Culture shift in advanced industrial society. European Sociological Review, 8(1), 95-98. Inglehart, R. (2010). Faith and freedom: Traditional and modern ways to happiness. In E. Diener, D.

Kahneman \& J. F. Helliwell (Eds.), International differences in well-being (351-397). New York: Oxford University Press.

Inglehart, R., \& Klingemann, H.-D. (2000). Genes, culture, democracy, and happiness. In E. Diener \& E. M. Suh (Eds.), Culture and subjective well-being (165-183). Cambridge, MA: MIT Press.

Joung, I. M. (1997). The relationship between marital status and health. Nederlands tijdschrift voor geneeskunde, 141(6), 277-282.

Kahneman, D. (1999). Objective happiness. In D. Kahneman, E. Diener \& N. Schwarz (Eds.), Well-being: Foundations of hedonic psychology (3-25). New York: Russell Sage Foundation Press.

Kahneman, D., \& Deaton, A. (2010). High income improves evaluation of life but not emotional wellbeing. Proceedings of the National Academy of Sciences, 107(38), 16489-16493. http://dx.doi.org/10.1073/pnas.1011492107

Kahneman, D., \& Krueger, A. B. (2006). Developments in the measurement of subjective well-being. Journal of Economic Perspectives, 20(1), 3-24. http://dx.doi.org/10.1257/089533006776526030

Katsaiti, M.-S. (2012). Obesity and happiness. Applied Economics, 44(31/33), 4101-4114. http://dx.doi.org/10.1080/00036846.2011.587779

Kushner, R. F., \& Foster, G. D. (2000). Obesity and quality of life. Nutrition, 16(10), 947-952. http://dx.doi.org/10.1016/S0899-9007(00)00404-4

Lane, R. E. (2000). The loss of happiness in market democracies. New Haven, CT: Yale University Press.

Lim, C., \& Putnam, R. D. (2010). Religion, social networks, and life satisfaction. American Sociological Review, 75(6), 914-933. http://dx.doi.org/10.1177/0003122410386686

Lucas, R. E., Diener, E., \& Suh, E. (1996). Discriminant validity of well-being measures. Journal of Personality and Social Psychology, 71(3), 616-628. http://dx.doi.org/10.1037/0022-3514.71.3.616

Lykken, D. T. (1999). Happiness: What studies on twins show us about nature, nurture, and the happiness setpoint. New York: Golden Books.

Marshall, R. D., Olfson, M., Hellman, F., Blanco, C., Guardino, M., \& Struening, E. L. (2001). Comorbidity, impairment, and suicidality in subthreshold PTSD. The American Journal of Psychiatry, 158(9), 1467-1473. http://dx.doi.org/10.1176/appi.ajp.158.9.1467

Maslow, A. H. (1943). A theory of human motivation. Psychological Review, 50(4), 370-396. http://dx.doi.org/10.1037/h0054346

Mastekaasa, A. (1992). Marriage and psychological well-being: Some evidence on selection into marriage. Journal of Marriage and Family, 54(4), 901-911. http://dx.doi.org/10.2307/353171

McMahon, D. M. (2006). Happiness : A history (1st ed.). New York: Atlantic Monthly Press.

Meulemann, H. (2001). Life satisfaction from late adolescence to mid-life: the impact of life success and success evaluation on the life satisfaction of former gymnasium students between ages 30 and 43 . Journal of Happiness Studies, 2(4), 445-465. http://dx.doi.org/10.1023/A:1013990011655

Murray, C. A. (1988). In pursuit: Of happiness and good government. New York: Simon and Schuster.

Murray, D. M., McKinlay, S. M., Martin, D., Donner, A. P., Dwyer, J. H., Raudenbush, S. W., \& Graubard, B. I. (1994). Design and Analysis Issues in Community Trials. Evaluation Review, 18(4), 493-514. http://dx.doi.org/10.1177/0193841X9401800407

Office for National Statistics. (2014). Statistical bulletin: Personal well-being in the UK, 2013/14. http://www.ons.gov.uk/ons/rel/wellbeing/measuring-national-well-being/personal-well-being-inthe-uk--2013-14/sb-personal-well-being-in-the-uk--2013-14.html

Oishi, S. (2012). The psychological wealth of nations: Do happy people make a happy society? Chichester, England: Wiley-Blackwell. http://dx.doi.org/10.1002/9781444354447

Oishi, S., Kesebir, S., \& Diener, E. (2011). Income inequality and happiness. Psychological Science, 22(9), 1095-1100. http://dx.doi.org/10.1177/0956797611417262

Oishi, S., \& Roth, D. P. (2009). The role of self-reports in culture and personality research: It is too early to give up on self-reports. Journal of Research in Personality, 43(1), 107-109.

http://dx.doi.org/10.1016/j.jp.2008.11.002 
Overton, R. C. (1998). A comparison of fixed-effects and mixed (random-effects) models for metaanalysis tests of moderator variable effects. Psychological Methods, 3(3), 354-379. http://dx.doi.org/10.1037/1082-989X.3.3.354

Parfit, D. (1984). Reasons and persons. Oxford, England: Oxford University Press.

Plagnol, A. C., \& Easterlin, R. A. (2008). Aspirations, attainments, and satisfaction: Life cycle differences between American women and men. Journal of Happiness Studies, 9(4), 601-619. http://dx.doi.org/10.1007/s10902-008-9106-5

Putnam, R. D. (2000). Bowling alone: The collapse and revival of American community. New York: Simon \& Schuster. http://dx.doi.org/10.1145/358916.361990

Rackham, H. (1934). Aristotle in 23 Volumes, Vol. 19, translated by H. Rackham. Cambridge, MA: Harvard University Press; London: William Heinemann Ltd.

Rothstein, H. R., Sutton, A. J., \& Borenstein, M. (2005). Publication bias in Meta-Analysis. In H.R. Rothstein, A.J. Sutton, \& M. Borenstein (Eds.), Publication bias in Meta-Analysis- Prevention, assessment and adjustments (2-3). West Sussex, England: John Wiley \& Sons, Ltd. http://dx.doi.org/10.1002/0470870168

Samanni, M., \& Holmberg, S. (2010). Quality of government makes people happy. QoG Working Paper Series, 1-36. The QOG Institute: University of Gothenburg.

Scanlon, T. (1993). Value, desire, and quality of life. In M. Nussbaum \& A. Sen (Eds.), The quality of life (185-200). Oxford, United Kingdom: Clarendon Press/Oxford University Press.

Schmidt, F. L., Oh, I.-S., \& Hayes, T. L. (2009). Fixed-versus random-effects models in meta-analysis: Model properties and an empirical comparison of differences in results. British Journal of Mathematical E Statistical Psychology, 62(1), 97-128. http://dx.doi.org/10.1348/000711007X255327

Seligman, M. E. P. (2002a). Authentic happiness: Using the new positive psychology to realize your potential for lasting fulfillment. New York: The Free Press.

Seligman, M. E. P. (2002b). Positive psychology, positive prevention, and positive therapy. In C. R. Snyder \& S. J. Lopez (Eds.), Handbook of positive psychology, 2, 3-12. New York: Oxford University Press.

Sen, A. K. (1999). Commodities and capabilities. Delhi; New York: Oxford University Press.

Shadish, W. R., Cook, T. D., \& Campbell, D. T. (2002). Experimental and quasi-experimental designs for generalized causal inference. Boston, MA: Wadsworth Cengage Learning.

Sterne, J. A., Gavaghan, D., \& Egger, M. (2000). Publication and related bias in meta-analysis: Power of statistical tests and prevalence in the literature. Journal of Clinical Epidemiology, 53(11), 1119-1129. http://dx.doi.org/10.1016/S0895-4356(00)00242-0

Stolle, D. (1998). Bowling together, bowling alone: The development of generalized trust in voluntary associations. Political Psychology, 19(3), 497-525.

Sumner, L. W. (2003). Welfare, happiness, and ethics (Reprint. ed.). New York: Oxford University Press.

Toulmin, S. E. (1961). Foresight and understanding: An inquiry into the aims of science. Bloomington, IN: Indiana University Press.

Triandis, H. C., \& Gelfand, M. J. (1998). Converging measurement of horizontal and vertical individualism and collectivism. Journal of Personality and Social Psychology, 74(1), 118-128. http://dx.doi.org/10.1037/0022-3514.74.1.118

Veenhoven, R. (1996). Developments in satisfaction-research. Social Indicators Research, 37(1), 1-46. http://dx.doi.org/10.1007/BF00300268

Veenhoven, R. (2008). Sociological theories of subjective well-being. In M. Eid \& R. J. Larsen (Eds.), The science of subjective well-being: A tribute to Ed Diener (44-61). New York: The Guilford Press.

Veenhoven, R. (2012). Evidence based pursuit of happiness: What should we know, do we know and can we get to know?(MRPA paper 41924). Rotterdam, The Netherlands: Erasmus Happiness Economics Research Organization.

Veenhoven, R. (2013). World database of happiness. http://worlddatabaseofhappiness.eur.nl/

Verme, P. (2007). Happiness and freedom in a world of heterogeneous values. Paper presented at the International Conference on Happiness and Public Policy, Bangkok, Thailand. 
Watson, D., Clark, L. A., \& Tellegen, A. (1988). Development and validation of brief measures of positive and negative affect: The PANAS scales. Journal of Personality and Social Psychology, 54(6), 1063-1070. http://dx.doi.org/10.1037/0022-3514.54.6.1063

Wilson, W. R. (1967). Correlates of avowed happiness. Psychological Bulletin, 67(4), 294-306. http://dx.doi.org/10.1037/h0024431

Winkelmann, L., \& Winkelmann, R. (1998). Why are the unemployed so unhappy? Evidence from panel data. Economica, 65(257), 1-15. http://dx.doi.org/10.1111/1468-0335.00111

World Values Survey (1981-2005). World Values Survey. http://www.worldvaluessurvey.org

Zak, P. J. (2011). Moral markets. Journal of Economic Behavior \& Organization, 77(2), 212-233.

http://dx.doi.org/10.1016/j.jebo.2010.09.004 


\section{Appendix A}

Abrams, M., Gerard, D., \& Timms, N. (Ed.) (1985). Values and social change in Britain. London: Macmillan in association with the European Value Systems Study Group.

Abramson, M., Angers, W., Cherepon, J., Kohut, M., \& Lalouch, H. (1981). Pilot analysis of a happiness questionnaire. Psychological Reports, 48(2), 570. http://dx.doi.org/10.2466/pr0.1981.48.2.570

Alesina, A., Di Tella, R., \& MacCulloch, R. (2004). Inequality and happiness: Are Europeans and Americans different? Journal of Public Economics, 88(9-10), 2009-2042. http://dx.doi.org/10.1016/j.jpubeco.2003.07.006

Allardt, E. (1976). Dimensions of welfare in a comparative Scandinavian study. Acta Sociologica, 19(3), 227-239. http://dx.doi.org/10.1177/000169937601900302

Allardt, E. (1981). Experiences from the comparative Scandinavian welfare study, with a bibliography of the project. European Journal of Political Research, 9(1), 101-113. http://dx.doi.org/10.1111/j.14756765.1981.tb00591.x

Andrews, F. M. (1991). Stability and change in levels and structure of subjective well-being: USA 1972 and 1988. Social Indicators Research, 25(1), 1-30. http://dx.doi.org/10.1007/BF00727649

Andrews, F. M., \& Withey, S. B. (1976). Social indicators of well-being: Americans' perceptions of life quality. New York: Plenum Press. http://dx.doi.org/10.1007/978-1-4684-2253-5

Ball, R., \& Chernova, K. (2008). Absolute income, relative income, and happiness. Social Indicators Research, 88(3), 497-529. http://dx.doi.org/10.1007/s11205-007-9217-0

Baltatescu, S. (2011). Subjective well-being and satisfaction with places of residence in the counties at the cross-border between Hungary and Romania. Eurolimes (Supplement), 395-403.

Beja, E., \& Yap, D. (2013). Counting happiness from the individual level to the group level. Social Indicators Research, 114(2), 621-637. http://dx.doi.org/10.1007/s11205-012-0165-y

Bergan, A., \& McConatha, J. T. (2001). Religiosity and life satisfaction. Activities, Adaptation \& Aging, 24(3), 23-34. http://dx.doi.org/10.1300/J016v24n03 02

Bergin, A. E. (1983). Religiosity and mental health: A critical reevaluation and meta-analysis. Professional Psychology: Research and Practice, 14(2), 170-184. http://dx.doi.org/10.1037/0735-7028.14.2.170

Bharadwaj, L., \& Wilkening, E. A. (1977). The prediction of perceived well-being. Social Indicators Research, 4(4), 421-439. http://dx.doi.org/10.1007/BF00353143

Binder, M. (2013). Innovativeness and subjective well-being. Social Indicators Research, 111(2), 561-578. http://dx.doi.org/10.1007/s11205-012-0020-1

Binder, M., \& Ward, F. (2013). The structure of subjective well-being: A vector autoregressive approach. Metroeconomica, 64(2), 361-400. http://dx.doi.org/10.1111/meca.12011

Bjørnskov, C. (2006). The multiple facets of social capital. European Journal of Political Economy, 22(1), 2240. http://dx.doi.org/10.1016/j.ejpoleco.2005.05.006

Bjørnskov, C., Dreher, A., \& Fischer, J. A. (2007). Cross-country determinants of life satisfaction: Exploring different determinants across groups in society. Social Choice and Welfare, 30(1), 119-173. http://dx.doi.org/10.1007/s00355-007-0225-4

Bjørnskov, C., Dreher, A., \& Fischer, J. A. V. (2007). The bigger the better? Evidence of the effect of government size on life satisfaction around the world. Public Choice, 130(3/4), 267-292. http://dx.doi.org/10.1007/s11127-006-9081-5

Bjørnskov, C., Dreher, A., \& Fischer, J. A. V. (2010). Formal institutions and subjective well-being: Revisiting the cross-country evidence. European Journal of Political Economy, 26(4), 419-430. http://dx.doi.org/10.1016/j.ejpoleco.2010.03.001

Bjørnskov, C., Gupta, N., \& Pedersen, P. (2008). Analyzing trends in subjective well-being in 15 European countries, 1973-2002. Journal of Happiness Studies, 9(2), 317-330. http://dx.doi.org/10.1007/s10902-007$\underline{9055-4}$

Böhnke, P. (2008). Does society matter? Life satisfaction in the enlarged Europe. Social Indicators Research, 87(2), 189-210. http://dx.doi.org/10.1007/s11205-007-9169-4

Böhnke, P., \& Kohler, U. (2010). Well-being and inequality. In S. Immerfall \& G. Therborn (Eds.), Handbook of European societies (629-666). New York: Springer. 
Bond, M. H., Lun, V. M. -C., \& Li, L. M. W. (2012). Religion and the life satisfaction of young persons around the world: Personal values and societal context. In G. Trommsdorff \& X. Chen (Eds.), Values, religion, and culture in adolescent development (123-145). Cambridge, England: Cambridge University Press.

Bortner, R. W., \& Hultsch, D. F. (1970). A multivariate analysis of correlates of life satisfaction in adulthood. Journal of Gerontology, 25(1), 41-47. http://dx.doi.org/10.1093/geronj/25.1.41

Bray, I., \& Gunnell, D. (2006). Suicide rates, life satisfaction and happiness as markers for population mental health. Social Psychiatry and Psychiatric Epidemiology, 41(5), 333-337. http://dx.doi.org/10.1007/s00127-006-0049-z

Brooks, A. C. (2008). Gross national happiness: Why happiness matters for America-And how we can get more of it. New York: Basic Books.

Bruni, L., \& Porta, P. L. (2005). Economics and happiness framing the analysis. Oxford: Oxford University Press. http://dx.doi.org/10.1093/0199286280.001.0001

Bruni, L., \& Stanca, L. (2008). Watching alone: Relational goods, television and happiness. Journal of Economic Behavior \& Organization, 65(3-4), 506-528. http://dx.doi.org/10.1016/j.jebo.2005.12.005

Buttel, F. H., Wilkening, E. A., \& Martinson, O. B. (1977). Ideology and social indicators of the quality of life. Social Indicators Research, 4(3), 353-369. http://dx.doi.org/10.1007/BF00353138

Camfield, L., Guillen-Royo, M., \& Velazco, J. (2010). Does needs satisfaction matter for psychological and subjective wellbeing in developing countries: A mixed-methods illustration from Bangladesh and Thailand. Journal of Happiness Studies, 11(4), 497-516. http://dx.doi.org/10.1007/s10902-009-9154-5

Campbell, A., Converse, P. E., \& Rodgers, W. L. (1976). The quality of American life: Perceptions, evaluations, and satisfactions. New York: Russell Sage Foundation.

Campbell, A., \& University of Michigan Institute for Social, R. (1981). The sense of well-being in America: Recent patterns and trends. New York: McGraw-Hill.

Cantril, H. (1965). Pattern of human concerns. New Brunswick, NJ: Rutgers University Press.

Cantril, H. (1977). The pattern of human concerns (ICPSR ed. ed.). Ann Arbor, MI: Inter-University Consortium for Political and Social Research.

Chang, W.-C. (2009). Religious attendance and subjective well-being in an Eastern-culture country: Empirical Evidence from Taiwan. Marburg Journal of Religion, 14(1), 30.

Cohn, M. A., Fredrickson, B. L., Brown, S. L., Mikels, J. A., \& Conway, A. M. (2009). Happiness unpacked: Positive emotions increase life satisfaction by building resilience. Emotion, 9(3), 361-368. http://dx.doi.org/10.1037/a0015952

Costa, F. M., Donovan, J. E., \& Jessor, R. (1992). Beyond adolescence: Problem behaviour and young adult development. Cambridge, England: Cambridge University Press.

Cummins, R. A., Eckersley, R., Pallant, J., Vugt, J. V., \& Misajon, R. (2003). Developing a national index of subjective wellbeing: The Australian Unity Wellbeing Index. Social Indicators Research, 64(2), 159-190. http://dx.doi.org/10.1023/A:1024704320683

Deaton, A. (2008). Income, health, and well-being around the world: Evidence from the Gallup World Poll. The Journal of Economic Perspectives, 22(2), 53-72. http://dx.doi.org/10.1257/jep.22.2.53

Debnath, R. M., \& Shankar, R. (2014). Does good governance enhance happiness: A cross nation study. Social Indicators Research, 116(1), 235-253. http://dx.doi.org/10.1007/s11205-013-0275-1

Diener, E. (1994). Assessing subjective well-being: Progress and opportunities. Social Indicators Research, 31(2), 103-157. http://dx.doi.org/10.1007/BF01207052

Diener, E. (1996). Subjective well-being in cross-cultural perspective. In H. Grad, A. Blanco, \& J. Georgas (Eds.), Key issues in cross-cultural psychology (319-330). Liese, The Netherlands: Swets \& Zeitlinger Publishers.

Diener, E. (2009). Culture and well-being: The collected works of Ed Diener (Social Indicators Research Series). Springer. http://dx.doi.org/10.1007/978-90-481-2352-0

Diener, E., Ng, W., Harter, J., \& Arora, R. (2010). Wealth and happiness across the world: Material prosperity predicts life evaluation, whereas psychosocial prosperity predicts positive feeling. Journal of Personality and Social Psychology, 99(1), 52-61. http://dx.doi.org/10.1037/a0018066 
Diener, E., Suh, E. M., Lucas, R. E., \& Smith, H. L. (1999). Subjective well-being: Three decades of progress. Psychological Bulletin, 125(2), 276-302. http://dx.doi.org/10.1037/0033-2909.125.2.276

Diener, E., \& Tov, W. (2007). Subjective well-being and peace. Journal of Social Issues, 63(2), 421-440. http://dx.doi.org/10.1111/i.1540-4560.2007.00517.x

Distante, R. (2013). Subjective well-being, income and relative concerns in the UK. Social Indicators Research, 113(1), 81-105. http://dx.doi.org/10.1007/s11205-012-0083-z

Di Tella, R., \& MacCulloch, R. (2006). Some uses of happiness data in economics. Journal of Economic Perspectives, 20(1), 25-46. http://dx.doi.org/10.1257/089533006776526111

Dorahy, M. J., Lewis, C. A., Schumaker, J. F., Akuamoah-Boateng, R., Duze, M. C., \& Sibiya, T. E. (1998). A cross-cultural analysis of religion and life satisfaction. Mental Health, Religion \& Culture, 1(1), 37-43. http://dx.doi.org/10.1080/13674679808406496

Dowley, K. M., \& Silver, B. D. (2005). Crossnational survey research and subnational pluralism. International Journal of Public Opinion Research, 17(2), 226-238. http://dx.doi.org/10.1093/ijpor/edh052

Drobnic, S., Beham, B., \& Präg, P. (2010). Good job, good life? Working conditions and quality of life in Europe. Social Indicators Research, 99(2), 205-225. http://dx.doi.org/10.1007/s11205-010-9586-7

Dush, C. M. K., \& Amato, P. R. (2005). Consequences of relationship status and quality for subjective well-being. Journal of Social and Personal Relationships, 22(5), 607-627. http://dx.doi.org/10.1177/0265407505056438

Easterlin, R. A., McVey, L. A., Switek, M., Sawangfa, O., \& Zweig, J. S. (2010). The happiness-income paradox revisited. Proceedings of the National Academy of Sciences, 107(52), 22463-22468. http://dx.doi.org/10.1073/pnas.1015962107

Easterlin, R. A., Morgan, R., Switek, M., \& Wang, F. (2012). China's life satisfaction, 1990-2010. Proceedings of the National Academy of Sciences, 109(25), 9775-9780. http://dx.doi.org/10.1073/pnas.1205672109

Fahey, T., \& Smyth, E. (2004). The link between subjective well-being and objective conditions in European societies. In W. A. Arts, \& L. Halman (Eds.), European values at the turn of the millennium (Vol. 7), 57-80. Leiden, The Netherlands: Koninklijke Brill NV.

Fernandez, R. M., \& Kulik, J. C. (1981). A multilevel model of life satisfaction: Effects of individual characteristics and neighborhood composition. American Sociological Review, 46(6), 840-850. http://dx.doi.org/10.2307/2095082

Ferriss, A. L. (2002). Religion and the quality of life. Journal of Happiness Studies, 3(3), 199-215. http://dx.doi.org/10.1023/A:1020684404438

Frey, B. S., Luechinger, S., \& Stutzer, A. (2009). The life satisfaction approach to valuing public goods: The case of terrorism. Public Choice, 138(3-4), 317-345. http://dx.doi.org/10.1007/s11127-008-9361-3

Gainer, M. (2013). Assessing happiness inequality in the welfare state: Self-reported happiness and the Rawlsian Difference Principle. Social Indicators Research, 114(2), 453-464. http://dx.doi.org/10.1007/s11205-012-0155-0

Ganglmair-Wooliscroft, A., Croft, A. G.-W., \& Lawson, R. (2008). Applying the international wellbeing index to investigate subjective wellbeing of New Zealanders with European and with Maori heritage. Kotuitui, 3(1), 57-72. http://dx.doi.org/10.1080/1177083x.2008.9522432

Georgellis, Y., Tsitsianis, N., \& Yin, Y. P. (2009). Personal values as mitigating factors in the link between income and life satisfaction: Evidence from the European Social Survey. Social Indicators Research, 91(3), 329-344. http://dx.doi.org/10.1007/s11205-008-9344-2

Glenn, N. D. (1975). The contribution of marriage to the psychological well-being of males and females. Journal of Marriage and Family, 37(3), 594-600. http://dx.doi.org/10.2307/350523

Glenn, N. D., \& McLanahan, S. (1981). The effects of offspring on the psychological well-being of older adults. Journal of Marriage and Family, 43(2), 409-421. http://dx.doi.org/10.2307/351391

Glenn, N. D., \& Weaver, C. N. (1979). A note on family situation and global happiness. Social Forces, 57(3), 960-967. http://dx.doi.org/10.1093/sf/57.3.960

Graham, C., \& Crown, S. (2014). Religion and wellbeing around the world: Social purpose, social time, or social insurance? International Journal of Wellbeing, 4(1), 1-27. http://dx.doi.org/10.5502/ijw.v4i1.1 
Graham, C., Eggers, A., \& Sukhtankar, S. (2004). Does happiness pay? An exploration based on panel data from Russia. Journal of Economic Behavior E Organization, 55(3), 319-342. http://dx.doi.org/10.1016/s0167-2681(04)00047-2

Graham, C., Inter American Development, B., \& Lora, E. (Eds.) (2009). Paradox and perception: Measuring quality of life in Latin America. Washington, DC: Brookings Institution Press.

Gropper, D. M., Lawson, R. A., \& Thorne, J. T., Jr. (2011). Economic freedom and happiness. The Cato Journal, 31, 237-255.

Grün, C., \& Klasen, S. (2003). Growth, inequality, and well-being: Intertemporal and global comparisons. CESifo Economic Studies, 49(4), 617-659. http://dx.doi.org/10.1093/cesifo/49.4.617

Gundelach, P., \& Kreiner, S. (2004). Happiness and life satisfaction in advanced European countries. Cross-Cultural Research: Official journal of the Society for Cross-Cultural Research, Sponsored by the Human Relations Area Files, Inc, 38(4), 359-386. http://dx.doi.org/10.1177/1069397104267483

Gurin, G. (1960). Americans view their mental health: A nationwide interview survey; A report to the staff director, Jack E. Ewal, 1960. New York: Basic Books.

Gurin, G., Veroff, J., \& Feld, S. (1984). Americans view their mental health, 1957. http://doi.org/10.3886/ICPSR03503.v1

Hackney, C. H., \& Sanders, G. S. (2003). Religiosity and mental health: A meta-analysis of recent studies. Journal for the Scientific Study of Religion, 42(1), 43-56. http://dx.doi.org/10.1111/1468-5906.t01-1-00160

Hadaway, C. K. (1978). Life satisfaction and religion: A reanalysis. Social Forces, 57(2), 636-643. http://dx.doi.org/10.1093/sf/57.2.636

Hall, J. F. (1973). Measuring the quality of life using sample surveys. Technology Assessment and Quality of Life, 93-101.

Hall, J. F. (1976). Subjective measures of quality of life in Britain: 1971 to 1975: Some developments and trends. Social Trends, 7(48), 14.

Halman, L. (1987). Traditie, secularisatie en individualisering: een studie naar de waarden van de Nederlanders in een Europese context. Tillburg, The Netherlands: University Press.

Hasegawa, H., \& Ueda, K. (2011). Measuring inequality of subjective well-being: A Bayesian approach. The Journal of Socio-Economics, 40(5), 700-708. http://dx.doi.org/10.1016/j.socec.2011.05.009

Hayo, B. (2007). Happiness in transition: An empirical study on Eastern Europe. Economic Systems, 31(2), 204-221.http://dx.doi.org/10.1016/j.ecosys.2006.08.003

Headey, B. (1981). The quality of life in Australia. Social Indicators Research, 9(2), 155-181. http://dx.doi.org/10.1007/BF00286195

Headey, B., Muffels, R., \& Wagner, G. G. (2010). Long-running German panel survey shows that personal and economic choices, not just genes, matter for happiness. Proceedings of the National Academy of Sciences, 107(42), 17922-17926. http://dx.doi.org/10.1073/pnas.1008612107

Headey, B., Muffels, R., \& Wagner, G. G. (2013). Choices which change life satisfaction: Similar results for Australia, Britain and Germany. Social Indicators Research, 112(3), 725-748. http://dx.doi.org/10.1007/s11205-012-0079-8

Headey, B., Schupp, J., Tucci, I., \& Wagner, G. G. (2010). Authentic happiness theory supported by impact of religion on life satisfaction: A longitudinal analysis with data for Germany. The Journal of Positive Psychology, 5(1), 73-82. http://dx.doi.org/10.1080/17439760903435232

Headey, B., Veenhoven, R., \& Wearing, A. (1991). Top-down versus bottom-up theories of subjective well-being. Social Indicators Research, 24(1), 81-100. http://dx.doi.org/10.1007/BF00292652

Herzog, A. R., Rodgers, W. L., \& Woodworth, J. (1982). Subjective well-being among different age groups (Research Report Series). Ann Arbor, MI: Institute for Social Research.

Heukamp, F. H., \& Ariño, M. A. (2011). Does country matter for subjective well-being? Social Indicators Research, 100(1), 155-170. http://dx.doi.org/10.1007/s11205-010-9610-y

Hoverd, W. J., \& Sibley, C. G. (2013). Religion, deprivation and subjective wellbeing: Testing a religious buffering hypothesis. International Journal of Wellbeing, 3(2), 182-196.

Howell, R. T., \& Howell, C. J. (2008). The relation of economic status to subjective well-being in developing countries: A meta-analysis. Psychological Bulletin, 134(4), 536-60. http://dx.doi.org/10.1037/0033-2909.134.4.536 
Inglehart, R., Foa, R., Peterson, C., \& Welzel, C. (2008). Development, freedom, and rising happiness: A global perspective (1981-2007). Perspectives on Psychological Science, 3(4), 264-285. http://dx.doi.org/10.1111/j.1745-6924.2008.00078.x

Jorm, A. F., \& Ryan, S. M. (2014). Cross-national and historical differences in subjective well-being. International Journal of Epidemiology, 43(2), 330-340. http://dx.doi.org/10.1093/ije/dyt188

Kaliterna Lipovčan, L., \& Prizmić-Larsen, Z. (2006). What makes Croats happy? Predictors of happiness in a representative sample. In A. Delle Fave (Ed.), Dimensions of well-being research: Research and intervention (60-74). Milano, Italy: FrancoAngeli.

Karabegovic, A., \& Amela, K. (2006). Economic freedom [Institutions and the impact of investment on growth] [Economic policy and the level of self-perceived well-being: An international comparison]. Fraser Forum, 28.

Kennedy, L. W., \& Mehra, N. (1985). Effects of social change on well-being: Boom and bust in a Western Canadian city. Social Indicators Research, 17(2), 101-113. http://dx.doi.org/10.1007/BF00302416

Kennedy, L. W., Northcott, H. C., \& Kinzel, C. (1978). Subjective evaluation of well-being: Problems and prospects. Social Indicators Research, 5(1-4), 457-474. http://dx.doi.org/10.1007/BF00352943

Koralewicz, J., \& Zagorski, K. (2009). Living conditions and optimistic orientation of Poles. International Journal of Sociology, 39(4), 10-44. http://dx.doi.org/10.2753/IJS0020-7659390401

Lemel, Y., \& Noll, H. H. (2002). Changing structures of inequality: A comparative perspective. Montréal: McGill-Queen's University Press.

Lim, C., \& Putnam, R. D. (2010). Religion, social networks, and life satisfaction. American Sociological Review, 75(6), 914-933. http://dx.doi.org/10.1177/0003122410386686

Luechinger, S., Meier, S., \& Stutzer, A. (2010). Why does unemployment hurt the employed? Evidence from the life satisfaction gap between the public and the private sector. Journal of Human Resources, 45(4), 998-1045. http://dx.doi.org/10.1353/jhr.2010.0024

Matlin, N. (1966). The demography of happiness: Master sample survey of health and welfare. Office of Research, Department of Health and Research Unit, School of Public Health.

McBride, M. (2001). Relative-income effects on subjective well-being in the cross-section. Journal of Economic Behavior \& Organization, 45(3), 251-278. http://dx.doi.org/10.1016/S0167-2681(01)00145-7

McGillivray, M., \& Markova, N. (2009). Global inequality in well-being dimensions. The Journal of Development Studies, 46(2), 371-378. http://dx.doi.org/10.1080/00220380903033280

McNamara, P. H., \& St. George, A. (1978). Blessed are the downtrodden? An empirical test. Sociological Analysis, 39(4), 303-320. http://dx.doi.org/10.2307/3709974

Mookherjee, H. N. (1992). A comparative assessment of life satisfaction in the United States: 1978-1988. The Journal of Social Psychology, 132(3), 407-409. http://dx.doi.org/10.1080/00224545.1992.9924717

Mookherjee, H. N. (1994). Effects of religiosity and selected variables on the perception of well-being. The Journal of Social Psychology, 134(3), 403-405. http://dx.doi.org/10.1080/00224545.1994.9711748

Noelle-Neumann, E. (1974). Lebensfreude-Kein Thema für die Kirche? Fragen zu einem Test über Bewegungs-und Mienenspiel von Katholiken. Herder Korrespondenz, 28(1), 41-47.

OECD. Statistics, Knowledge and Policy 2007: Measuring and fostering the progress of societies. Paris: OECD Publishing.

Okulicz-Kozaryn, A. (2009). Religiosity and life satisfaction across nations. Mental Health, Religion $\mathcal{E}$ Culture, 13(2), 155-169. http://dx.doi.org/10.1080/13674670903273801

Ott, J. (2005). Level and inequality of happiness in nations: Does greater happiness of a greater number imply greater inequality in happiness? Journal of Happiness Studies, 6(4), 397-420.

http://dx.doi.org/10.1007/s10902-005-8856-6

Ouweneel, P. (1987). Geluk volgt welvaart. Economische Statistische Berichten, 3622, 840-842.

Ouweneel, P. (2002). Social security and well-being of the unemployed in 42 nations. Journal of Happiness Studies, 3(2), 167-192. http://dx.doi.org/10.1023/A:1019619324661

Ovaska, T., \& Takashima, R. (2006). Economic policy and the level of self-perceived well-being: An international comparison. The Journal of Socio-Economics, 35(2), 308-325.

http://dx.doi.org/10.1016/i.socec.2005.11.054 
Palisi, B. J., \& Canning, F. C. (1983). Urbanism and social psychological well-being: A cross-cultural test of three theories. The Sociological Quarterly, 24(4), 527-543. http://dx.doi.org/10.1111/j.15338525.1983.tb00717.x

Peacock, J. R., \& Poloma, M. M. (1999). Religiosity and life satisfaction across the life course. Social Indicators Research, 48(3), 319-343. http://dx.doi.org/10.1023/A:1006928028270

Pontin, E., Schwannauer, M., Tai, S., \& Kinderman, P. (2013). A UK validation of a general measure of subjective well-being: The modified BBC subjective well-being scale (BBC-SWB). Health and Quality of Life Outcomes, 11, 150-159. http://dx.doi.org/10.1186/1477-7525-11-150

Rojas, M. (2005). A conceptual-referent theory of happiness: Heterogeneity and its consequences. Social Indicators Research, 74(2), 261-294. http://dx.doi.org/10.1007/s11205-004-4643-8

Rojas, M. (2007). Heterogeneity in the relationship between income and happiness: A conceptualreferent-theory explanation. Journal of Economic Psychology, 28(1), 1-14. http://dx.doi.org/10.1016/j.joep.2005.10.002

Rojas, M., \& Veenhoven, R. (2013). Contentment and affect in the estimation of happiness. Social Indicators Research, 110(2), 415-431. http://dx.doi.org/10.1007/s11205-011-9952-0

Rule, S. (2007). Religiosity and quality of life in South Africa. Social Indicators Research, 81(2), 417-434. http://dx.doi.org/10.1007/s11205-006-9005-2

Samanni, M., \& Holmberg, S. (2010). Quality of government makes people happy. QoG Working Paper Series, 1-36. The QOG Institute: University of Gothenburg.

Schubert, C. (2012). Pursuing happiness. Kyklos, 65(2), 245-261. http://dx.doi.org/10.1111/j.1467$\underline{6435.2012 .00537 . x}$

Schütz, E., Sailer, U., Al Nima, A., Rosenberg, P., Andersson, A. A., Archer, T., \& Garcia, D. (2013). The affective profiles in the USA: Happiness, depression, life satisfaction, and happiness-increasing strategies. PeerJ (San Francisco, CA), 1(8), e156. http://dx.doi.org/10.7717/peerj.156

Schyns, P. (1998). Crossnational differences in happiness: Economic and cultural factors explored. Social Indicators Research, 43(1-2), 3-26. http://dx.doi.org/10.1023/A:1006814424293

Selim, S. (2008). Life satisfaction and happiness in Turkey. Social Indicators Research, 88(3), 531-562. http://dx.doi.org/10.1007/s11205-007-9218-z

Shemyakina, O. N., \& Plagnol, A. C. (2013). Subjective well-being and armed conflict: Evidence from Bosnia-Herzegovina. Social Indicators Research, 113(3), 1129-1152. http://dx.doi.org/10.1007/s11205$\underline{012-0131-8}$

Sigelman, L. (1981). Is ignorance bliss? A reconsideration of the folk wisdom. Human Relations, 34(11), 965-974. http://dx.doi.org/10.1177/001872678103401104

Snoep, L. (2008). Religiousness and happiness in three nations: A research note. Journal of Happiness Studies, 9(2), 207-211. http://dx.doi.org/10.1007/s10902-007-9045-6

Spreitzer, E., Snyder, E. E., \& Larson, D. (1975). Age, marital status, and labor force participation as related to life satisfaction. Sex Roles, 1(3), 235-247. http://dx.doi.org/10.1007/BF00287372

Stevenson, B., \& Wolfers, J. (2008). Economic growth and subjective well-being: Reassessing the Easterlin paradox. Brookings Papers on Economic Activity, 2008, 1-102. http://dx.doi.org/10.1353/eca.0.0001

Tavits, M. (2008). Representation, corruption, and subjective well-being. Comparative Political Studies, 41(12), 1607-1630. http://dx.doi.org/10.1177/0010414007308537

Taylor, P. (2008). Republicans-still happy campers (S. Trends, Trans.) Pew Research Social E Demographic Trends (1-15).

Thoits, P. A., \& Hewitt, L. N. (2001). Volunteer work and well-being. Journal of Health and Social Behavior, 42(2), 115-131. http://dx.doi.org/10.2307/3090173

Toulmin, S. E. (1961). Foresight and understanding: An inquiry into the aims of science. Bloomington, IN: Indiana University Press.

Uglanova, E. A. (2014). Gender dimensions of subjective well-being in Russia. In E. Eckermann (Ed.), Gender, lifespan and quality of life, Social Indicators Research Series, 53, 135-155. Netherlands: Springer. http://dx.doi.org/10.1007/978-94-007-7829-0 9 
Uglanova, E. A., \& Staudinger, U. M. (2013). Zooming in on life events: Is Hedonic adaptation sensitive to the temporal distance from the event? Social Indicators Research, 111(1), 265-286. http://dx.doi.org/10.1007/s11205-012-0004-1

van Hemert, D. A., van de Vijver, F. J. R., \& Poortinga, Y. H. (2002). The Beck Depression inventory as a measure of subjective well-being: A cross-national study. Journal of Happiness Studies, 3(3), 257-286. http://dx.doi.org/10.1023/A:1020601806080

van Praag, B. M. S., Frijters, P., \& Ferrer-i-Carbonell, A. (2003). The anatomy of subjective well-being. Journal of Economic Behavior \& Organization, 51(1), 29-49. http://dx.doi.org/10.1016/S01672681(02)00140-3

Veenhoven, R. (1984). Conditions of happiness. Dordrecht, Holland; Hingham, MA: D. Reidel. Sold and distributed in the U.S.A. and Canada by Kluwer Boston Academic Publishers. http://dx.doi.org/10.1007/978-94-009-6432-7

Veenhoven, R. (1989). National wealth and individual happiness. In Gruert, K.G. \& Olander, M. (Eds.) Understanding economic behavior, 9-32. Netherlands: Springer. http://dx.doi.org/10.1007/978-94-0092470-3 2

Veenhoven, R. (1993). Happiness in nations. Studies in Socio-Cultural Transformation. Rotterdam, Netherlands: Erasmus University.

Veenhoven, R. (1996). Leefbaarheid van landen. Universiteit Utrecht.

Veenhoven, R. (1999). Op zoek naar een menselijke maat. Leefbaarheid van de individualistische samenleving. Rekenschap, 46(2), 83-95.

Veenhoven, R. (1999). Quality-of-life in individualistic society: A comparison of 43 nations in the early 1990s. Social Indicators Research, 48(2), 157-186. http://dx.doi.org/10.1023/A:1006923418502

Veenhoven, R. (2000). Freedom and happiness: A comparative study in forty-four nations in the early 1990s. In E. Diener \& E. M. Suh (Eds.), Culture and subjective well-being (257-288). Cambridge, MA: MIT Press.

Veenhoven, R. (2001). What do we know about happiness. Paper presented the Dialogue on Gross National Happiness, Woudschoten, Zeist, The Netherlands.

Veenhoven, R. (2004). Happiness as a public policy aim: The greatest happiness principle. Positive Psychology in Practice (658-678). Hoboken, NJ: John Wiley \& Sons, Inc.

Veenhoven, R. (2004). Veiligheid en Geluk. In E. R. Muller (Ed.), Veiligheid studies over inhoud, organisatie en maatregelen. The Netherlands: Kluwer.

Veenhoven, R. (2005). Apparent quality-of-life in nations: How long and happy people live. Social Indicators Research, 71(1-3), 61-86. http://dx.doi.org/10.1007/1-4020-3602-7 3

Veenhoven, R. (2005). Inequality of happiness in nations. Journal of Happiness Studies, 6(4), 351-355. http://dx.doi.org/10.1007/s10902-005-0003-x

Veenhoven, R. (2005). Is life getting better?: How long and happily do people live in modern society? European Psychologist, 10(4), 330-343. http://dx.doi.org/10.1027/1016-9040.10.4.330

Veenhoven, R. (2005). Return of inequality in modern society? Test by dispersion of life-satisfaction across time and nations. Journal of Happiness Studies, 6(4), 457-487. http://dx.doi.org/10.1007/s10902$\underline{005-8858-4}$

Veenhoven, R. (2007). Greater happiness for a greater number. Journal of Happiness Studies, 11(5), 605-629. http://dx.doi.org/10.1007/s10902-010-9204-z

Veenhoven, R. (2008). Healthy happiness: effects of happiness on physical health and the consequences for preventive health care. Journal of Happiness Studies, 9(3), 449-469. http://dx.doi.org/10.1007/s10902006-9042-1

Veenhoven, R. (2009). Well-being in nations and well-being of nations: Is there a conflict between individual and society? Social Indicators Research, 91(1), 5-21. http://dx.doi.org/10.1007/s11205-0089323-7

Veenhoven, R. (2010). Life is getting better: Societal evolution and fit with human nature. Social Indicators Research, 97(1), 105-122. http://dx.doi.org/10.1007/s11205-009-9556-0

Veenhoven, R., \& Ouweneel, P. (1989). Het Rendement van de Verzorgingsstaat (The revenues of the welfare state). Economisch Statistische Berichten (April 26), 419-420. 
Veenhoven, R., \& Ouweneel, P. (1995). Livability of the welfare-state: Appreciation-of-life and length-oflife in nations varying in state-welfare-effort. Social Indicators Research, 36(1), 1-48. http://dx.doi.org/10.1007/BF01079395

Veroff, J., Douvan, E. A. M., \& Kulka, R. A. (1981). The inner American: A self-portrait from 1957 to 1976. New York: Basic Books.

Welsch, H. (2002). Preferences over prosperity and pollution: Environmental valuation based on happiness surveys. Kyklos, 55(4), 473-494. http://dx.doi.org/10.1111/1467-6435.00198

Wessman, A. E. (1956). A psychological inquiry into satisfactions and happiness. Princeton, NJ: Princeton University.

Wilkening, E. A., \& McGranahan, D. (1978). Correlates of subjective well-being in Northern Wisconsin. Social Indicators Research, 5(1-4), 211-234. http://dx.doi.org/10.1007/BF00352930

Williams, K. (2003). Has the future of marriage arrived? A contemporary examination of gender, marriage, and psychological well-being. Journal of Health and Social Behavior, 44(4), 470-487. http://dx.doi.org/10.2307/1519794

Wilson, W. R. (1967). Correlates of avowed happiness. Psychological Bulletin, 67(4), 294-306. http://dx.doi.org/10.1037/h0024431

Winkelmann, L., \& Winkelmann, R. (1998). Why are the unemployed so unhappy? Evidence from panel data. Economica, 65(257), 1-15. http://dx.doi.org/10.1111/1468-0335.00111

Wooden, M., \& Li, N. (2014). Panel conditioning and subjective well-being. Social Indicators Research, 117(1), 235-255. http://dx.doi.org/10.1007/s11205-013-0348-1 